\title{
Ghrelin and lipid metabolism: key partners in energy balance
}

\author{
Luis Varela ${ }^{1,2^{\star}}$, María J Vázquez ${ }^{1,2^{\star}}$, Fernando Cordido ${ }^{3,4}$, Rubén Nogueiras ${ }^{1,2}$, \\ Antonio Vidal-Puig ${ }^{5}$, Carlos Diéguez ${ }^{1,2}$ and Miguel López ${ }^{1,2}$

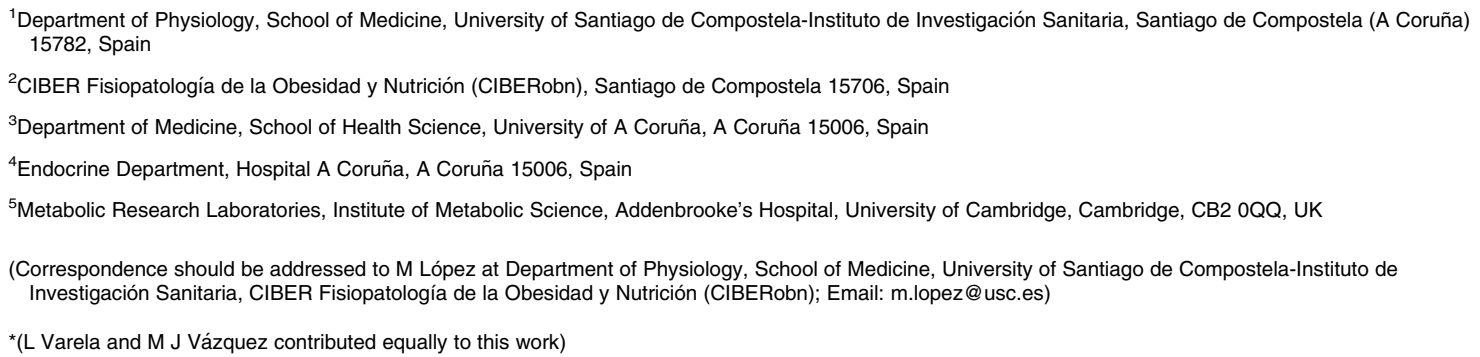

\begin{abstract}
Ghrelin, the endogenous ligand of the GH secretagogue receptor, has a pleiotropic role in the modulation of energy balance. Recent evidence has demonstrated that besides its orexigenic role, ghrelin regulates central and peripheral lipid metabolism through specific control of hypothalamic AMP-activated protein kinase (AMPK), a critical metabolic gauge regulating both cellular and whole-body energy homeostasis. In this review, we summarize the new milestones of ghrelin's actions on energy balance, with particular focus on its molecular interaction with hypothalamic AMPK and fatty acid metabolism. Understanding this new metabolic pathway can provide new therapeutic targets for the treatment of obesity and the metabolic syndrome.
\end{abstract}

Journal of Molecular Endocrinology (2011) 46, R43-R63

\section{Ghrelin: a stomach-derived peptide modulating energy balance}

A large degree of attention has surrounded the prospect of ghrelin becoming a key factor in the fight against obesity. This 28 amino acid peptide hormone, with orexigenic properties produced in the stomach (Kojima et al. 1999, Tschop et al. 2000, Nakazato et al. 2001, Seoane et al. 2003, Nogueiras et al. 2004, López et al. 2008a), shows several characteristics that lead researchers to believe that its potential as antiobesity target is genuine (Foster-Schubert \& Cummings 2006, Zorrilla et al. 2006). Investigations involving both humans and rodents have shown that ghrelin promotes feeding, weight gain, and adiposity (Tschop et al. 2000, Wren et al. 2001a). In fact, there is an inverse relationship between circulating ghrelin levels and body weight (Tschop et al. 2001b). Opposite, increased levels of ghrelin have been detected in patients diagnosed with Prader-Willi syndrome (Cummings et al. 2002). Moreover, research using ghrelin knockout (KO) mice (Wortley et al. 2005) or ghrelin receptor KO (GHS-R KO) mice (Zigman et al. 2005) has demonstrated that lack of ghrelin or ghrelin signaling protects against diet-induced obesity. Altogether, these data demonstrate that ghrelin is an important hormonal signal, promoting feeding and modulating circadian control of feeding patterns in humans and rodents (Cummings et al. 2001, Tschop et al. 2001a, Drazen et al. 2006).

\section{The 'classical' mechanism mediating ghrelin orexigenic effect}

The effect of ghrelin on feeding is mediated through the GH secretagogue receptor la (GHS-R 1a), as indicated by the lack of ghrelin's orexigenic effect in GHS-R KO mice (Sun et al. 2004). The relevance of this receptor is further supported by anatomical data showing that GHS-R 1a is highly expressed in hypothalamic cell populations that regulate feeding and body weight homeostasis, such as agouti-related peptide/neuropeptide Y (AGRP/NPY) neurons in the arcuate nucleus (ARC) and fatty acid synthase (FAS) neurons in the ventromedial nucleus (VMH; 
Bennett et al. 1997, Guan et al. 1997, Tannenbaum et al. 1998, Willesen et al. 1999, Mitchell et al. 2001, Nogueiras et al. 2004, Smith 2005, Zigman et al. 2006, López et al. 2008a, Lage et al. 2010). GHS-R 1a expression is not widespread, as it is absent in other regions, such as the lateral hypothalamic area (LHA; Guan et al. 1997), where a large number of orexigenic cell populations, such as orexins (OXs; Broberger et al. 1998, Elias et al. 1998, de Lecea et al. 1998, Peyron et al. 1998, Sakurai et al. 1998, Horvath et al. 1999, Seoane et al. 2003) and melanin-concentrating hormone (MCH)-producing neurons are located (Nahon et al. 1989, Bittencourt et al. 1992, Qu et al. 1996).

Along with this morphological evidence, central treatment with ghrelin massively increases the mRNA expression of the orexigenic neuropeptides AGRP and NPY in the ARC (Fig. 1), in fed or fasted rodents, an effect that is gender independent (Kamegai et al. 2001, Nakazato et al. 2001, Seoane et al. 2003, Lage et al. 2010). Ghrelin has also been reported to inhibit the firing of proopiomelanocortin (Pomc) neurons by increasing the frequency of spontaneous synaptic $\gamma$-aminobutyric acid release onto them (Cowley et al. 2003, Andrews et al. 2008), without affecting Pomc mRNA expression (Kamegai et al. 2000, 2001). Confirming that ghrelin's orexigenic effect is mediated by specific modulation of AGRP/NPY neurons in the ARC, no change was demonstrated in the mRNA levels of the other feeding-promoting neuropeptides, such as $\mathrm{MCH}$ and prepro-OX (Seoane et al. 2003). The physiological relevance of this molecular mechanism was firmly established using ghrelin in $\mathrm{KO}$ mice. Of interest, AGRP KO or NPY KO responded normally to ghrelin; however, the double AGRP/NPY KO failed to respond

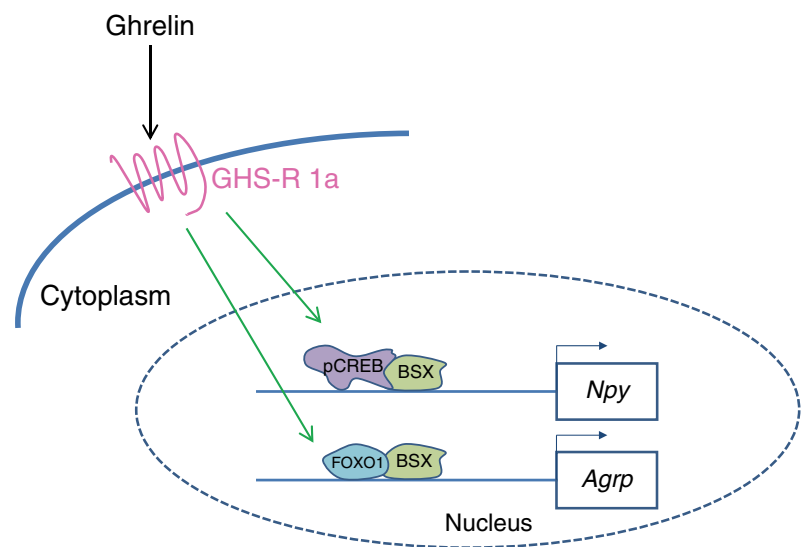

Figure 1 The 'classical' mechanism under ghrelin orexigenic effect. Ghrelin, acting on GH secretagogue receptor 1a (GHS-R 1a), stimulates the expression of hypothalamic homeobox domain transcription factor (BSX), forkhead box O1 (FOXO1), and the phosphorylated cAMP response-element-binding protein (pCREB). Subsequently, agouti-related peptide (Agrp) and neuropeptide $Y(N p y)$ gene expressions are increased in the arcuate nucleus of the hypothalamus (ARC). to ghrelin, indicating the existence of redundancy among these two neuropeptides as mediators of ghrelin's orexigenic action (Chen et al. 2004).

In addition to the control of the circadian patterns of feeding, the interaction between ghrelin and ARC neurons is also important in the metabolic adaptation to fasting, a situation characterized by elevated ghrelincirculating levels (Tschop et al. 2000, Wren et al. 2001a, Nogueiras et al. 2004, López et al. 2008a). This is demonstrated by the fact that starvation-induced hunger and food intake are suppressed after central administration of anti-ghrelin antiserum (Nakazato et al. 2001). Indeed, it is worth mentioning that even in this state of hyperghrelinemia, the administration of this peptide to food-deprived rats led to a further increase in Agrp and Npy mRNA contents in the ARC, suggesting that this interaction is fundamental for hunger to occur (Seoane et al. 2003). It is also important that the ghrelin-induced fasting effect is also mediated by specific modulation of GHS-R. Thus, in the ARC of fasted rats (and also of obese Zucker rats, which lack leptin signaling), GHS-R expression is significantly increased in comparison to controls, an effect that can be blunted with central leptin replacement (Nogueiras et al. 2004). The physiological relevance of leptin action on GHS-R is unclear but it has been proposed that, considering that GHS-R is reported to be constitutively active (Holst $e t$ al. 2003), leptin downregulates GHS-R expression in the ARC in an attempt to decrease orexigenic signaling (Nogueiras et al. 2004). Consistently, ghrelin significantly increased GHS-R expression in the ARC of normal rats (Bennett et al. 1997, Nogueiras et al. 2004), demonstrating that both leptin and ghrelin have a dual and opposite role in modulating the GHS-R expression in the ARC.

\section{BSX, forkhead box 01, and CREB are the key transcription factors in ghrelin receptor signaling pathway}

Although the role of ghrelin as the main modulator of ARC-derived neuropeptides is well established, the molecular mechanisms mediating this action have just been identified. It has been recently reported that the hypothalamic homeobox domain transcription factor BSX is highly expressed in AGRP/NPY neurons in the ARC and regulates ghrelin's stimulatory effect on Agrp and $N p y$ gene expression in male and female rodents (Sakkou et al. 2007, Nogueiras et al. 2008a, Lage et al. 2010). Although both genes share BSX as a common transcriptional factor, BSX needs to interact with another two transcription factors to activate Agrp and Npy mRNA expression: the forkhead box O1 (FOXO1) for Agrp gene and the phosphorylated cAMP responseelement-binding protein (pCREB) for Npy gene 
respectively (Shimizu-Albergine et al. 2001, Kitamura et al. 2006, Nogueiras et al. 2008a, Lage et al. 2010). Our group has shown that BSX, FOXO1, and pCREB protein expression in the hypothalamus are stimulated after central ghrelin administration, also in a genderindependent manner (Fig. 1; Lage et al. 2010). Interestingly, the ghrelin-BSX-FOXO1-pCREPAGRP/NPY pathway seems to exhibit a nucleus-specific pattern, since BSX expression in the dorsomedial nucleus of the hypothalamus (DMH) is unaffected by central ghrelin treatment (Nogueiras et al. 2008a).

The ghrelin-induced increase in FOXO1 protein levels is particularly interesting, since it affects both the nonphosphorylated (FOXO1) and the phosphorylated (pFOXO1) forms (Lage et al. 2010). Recent evidence has shown that hormonal signals, such as leptin and insulin, regulate Agrp and Pomc gene expression through modulation of the balance between FOXO1 (active form) and pFOXO1 (inactive form). Thus, leptin and insulin promote pFOXO1 and prevent its translocation to the nucleus (Kim et al. 2006). This results in increased expression of Pomc (Belgardt $e t$ al. 2008, Ernst et al. 2009, Plum et al. 2009) and decreased expression of Agrp (Kitamura et al. 2006). Quite opposite to leptin and insulin, we demonstrated that central ghrelin administration increased both hypothalamic FOXO1 and pFOXO1 to a similar extent. Consistent with previous literature, elevated levels of FOXO1 would be the mechanism leading to an increased transcription rate of the Agrp gene by ghrelin (Kitamura et al. 2006); however, the physiological relevance of increased pFOXO1 is unclear. Recent evidence has revealed that in pancreatic $\beta$-cells, ghrelin also stimulates both FOXO1 and pFOXO1 (Wang et al. $2010 a$ ). In this context, increased levels of pFOXO1 after ghrelin treatment elicit a protective effect against lipotoxicity, as shown by inhibition of endoplasmic reticulum (ER) stress and reduced levels of $\mathrm{C} / \mathrm{EBP}$ homologous protein (CHOP-10; Wang et al. 2010a), a pro-apoptotic member of the C/EBP family of transcription factors (Ron \& Habener 1992, Oyadomari \& Mori 2004), which is known to inhibit cell differentiation in response to metabolic stress (Tang \& Lane 2000, Martínez de Morentin et al. 2010b, de Morentin \& López 2010, Wang et al. 2010b). Similarly, ghrelin seems to protect against lipotoxicity-induced apoptosis and ER stress in an ischemic heart model (Zhang et al. 2009). Consistent with these observations, we demonstrated that ghrelin reduces the hypothalamic levels of CHOP-10 and the phosphorylated form of its upstream regulator phosphorylated eukaryotic translation initiation factor $2 \alpha$ (peIF2 $\alpha$; Lage et al. 2010). Taking into account that 1) hypothalamic ER stress has recently been suggested as a pathophysiological mechanism mediating leptin resistance and obesity (Hosoi et al. 2008, Zhang et al. 2008, Ozcan et al. 2009, Martínez de
Morentin et al. 2010b, de Morentin \& López 2010, Ropelle et al. 2010) and 2) central ghrelin administration increases hypothalamic reactive oxygen species (ROS; Andrews et al. 2008), which are well-recognized ER-stress inducers (Lee et al. 2007, Tagawa et al. 2008, Medina-Gomez et al. 2009, Santos et al. 2009, Martínez de Morentin et al. 2010b), we have recently proposed that ghrelin-induced elevation in hypothalamic pFOXO1 might be part of an allostatic response protecting against ER stress (Lage et al. 2010), a hypothesis that will involve further investigation.

\section{Hypothalamic fatty acid metabolism: a housekeeping pathway modulating whole-body energy balance}

Fatty acids are derived either from the diet or by de novo synthesis. The basic pathway for de novo fatty acid synthesis is summarized in Fig. 2 (Ruderman et al. 2003, Dowell et al. 2005, López et al. 2007, Lage et al. 2008, Martínez de Morentin et al. 2010a). Under lipogenic conditions, excess glucose in the cell is first converted to pyruvate via glycolysis in the cytoplasm. Pyruvate enters the mitochondria and is converted to acetyl-CoA and transported as citrate from the mitochondria into the cytoplasm. ATP citrate lyase then reconverts citrate to acetyl-CoA. Acetyl-CoA carboxylase (ACC) catalyzes the carboxylation of acetyl-CoA to malonyl-CoA in an ATP-dependent manner. Acetyl-CoA and malonyl-CoA are then used as the substrates for the production of palmitate by the seven enzymatic reactions catalyzed by FAS, at the expense of NADPH. The synthesis step of malonyl-CoA can be reversibly regulated as malonylCoA decarboxylase (MCD) converts malonyl-CoA back to acetyl-CoA. The resulting saturated fatty acid molecule produced by FAS can be subsequently desaturated to form unsaturated fatty acids, to contribute to the triglyceride pool, or be directed to specific biosynthetic pathways for the synthesis of phospholipids and derivatives for membrane and signaling functions (Kahn et al. 2005, López et al. 2007). Alternatively, fatty acids can also be further metabolized depending on requirements. During fatty acid oxidation, fatty acids are first activated in the outer mitochondrial membrane in a reaction catalyzed by long-chain fatty acyl-CoA synthetase. Next, they are translocated to the mitochondrial matrix, by the action of carnitine palmitoyltransferase 1 and 2 (CPT1 and CPT2), where oxidation takes place (Kahn et al. 2005, López et al. 2007). The complete oxidation of a palmitate molecule (C16:0) yields 129 molecules of ATP.

The activities of ACC and MCD are regulated by phosphorylation by AMP-activated protein kinase (AMPK). AMPK is a serine/threonine protein kinase 


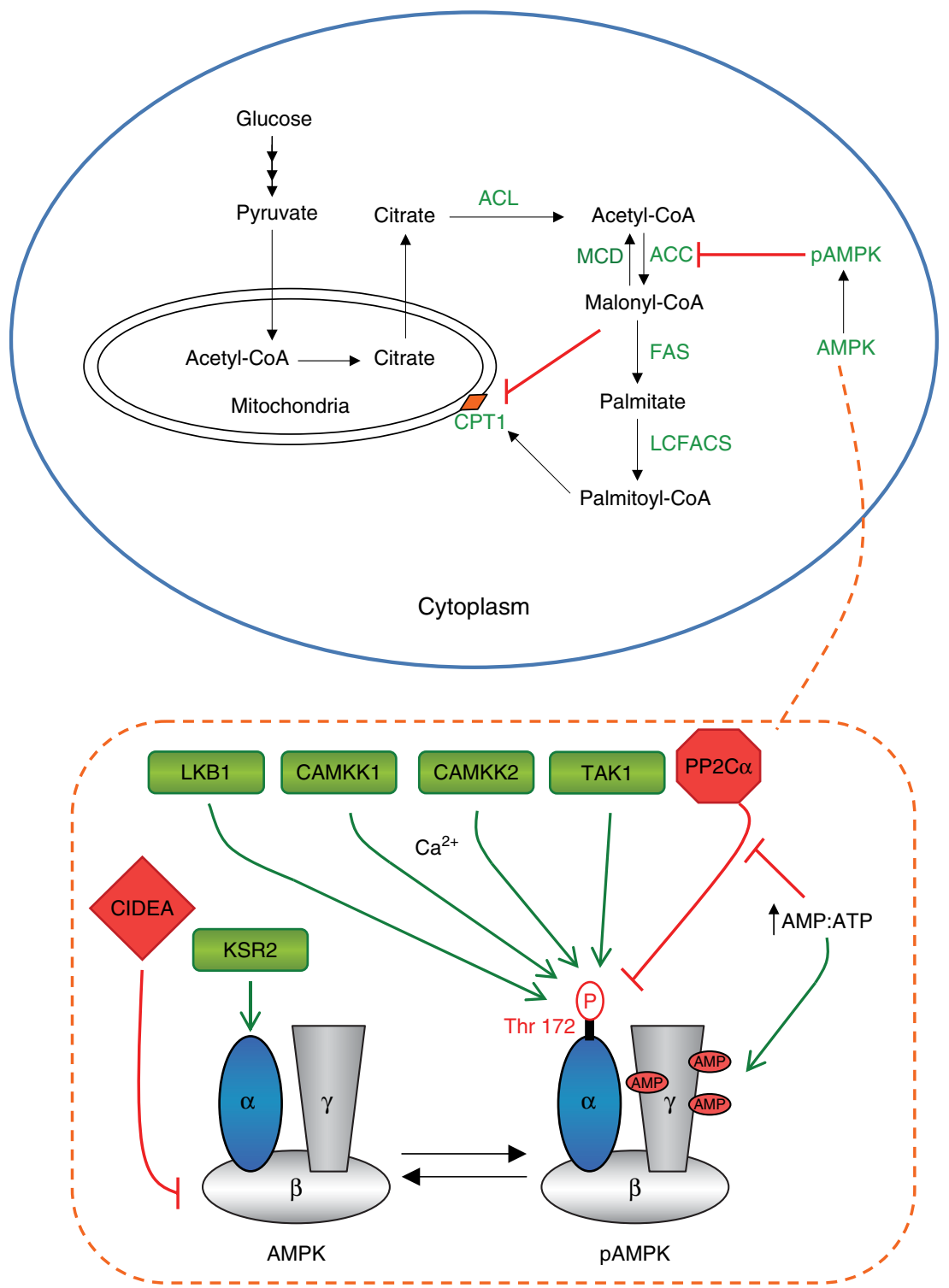

Figure 2 Fatty acid synthesis pathway. Excess glucose in the cell is first converted to pyruvate via glycolysis in the cytoplasm. Pyruvate enters the mitochondria and is converted to acetyl-CoA and transported as citrate from the mitochondria to the cytoplasm. ATP citrate lyase (ACL) then reconverts citrate to acetyl-CoA. Acetyl-CoA carboxylase (ACC) catalyzes the carboxylation of acetyl-CoA to malonylCoA. Both acetyl-CoA and malonyl-CoA are then used as the substrates for the production of palmitate catalyzed by fatty acid synthase (FAS). Malonyl-CoA decarboxylase (MCD) converts malonyl-CoA back to acetyl-CoA. Fatty acids are esterified in a reaction catalyzed by long-chain fatty acyl-CoA synthetase (LCFACS). Carnitine palmitoyltransferase 1 (CPT1) is the enzyme importing long-chain fatty acylCoA, such as palmitoyl-CoA, into the mitochondria for fatty acid oxidation; CPT1 activity is allosterically inhibited by malonyl-CoA. The resulting saturated fatty acid molecule produced by FAS can be further metabolized depending on the requirements, desaturated to form unsaturated fatty acids, derived to triglyceride molecules, or channeled to a range of phospholipids and derivatives for membrane and signaling functions. AMP-activated protein kinase (AMPK) is a serine/threonine protein kinase composed of a catalytic subunit ( $\alpha 1$ or $\alpha 2)$ and two regulatory subunits ( $\beta 1$ or $\beta 2$ and $\gamma 1$ or $\gamma 2$ or $\gamma 3$ ), which controls ACC, MCD, and FAS activities. Upstream regulation of AMPK is mediated by a complex mechanism involving several proteins such as LKB1 $\mathrm{Ca}^{2+}$ /calmodulin-dependent protein kinase kinase 1 or 2 (CAMKK1 or CAMKK2), transforming growth factor- $\beta$-activated kinase (TAK1), kinase suppressor of Ras (KSR2), protein phosphatase 2C $\alpha(\mathrm{PP} 2 \mathrm{C} \alpha)$, and cell-death-inducing-like-effector A (CIDEA), as well as cellular AMP concentration.

composed of a catalytic subunit ( $\alpha 1$ or $\alpha 2$ ) and two regulatory subunits ( $\beta 1$ or $\beta 2$ and $\gamma 1$ or $\gamma 2$ or $\gamma 3$ ). AMPK is activated by phosphorylation on Thr172 of the $\alpha$ subunit, a process catalyzed by LKB1 or
$\mathrm{Ca}^{2+} /$ calmodulin-dependent protein kinase kinase 1 or 2 (CAMKK1 or CAMKK2; Ruderman et al. 2003, Hawley et al. 2005, Kahn et al. 2005, Woods et al. 2005, Carling et al. 2008, Lage et al. 2008, Martínez de 
Morentin et al. 2010a). Transforming growth factor- $\beta$ activated kinase (TAK1; Xie et al. 2006) also activates AMPK, and kinase suppressor of Ras (KSR2) interacts with the $\alpha 1$ subunit of AMPK, modulating its activity (Costanzo-Garvey et al. 2009). The current data also point out that protein phosphatase 2C $\alpha$ (PP2C $\alpha)$ inactivates AMPK by dephosphorylation (Steinberg et al. 2006a, Martínez de Morentin et al. 2010a). AMPK is also allosterically activated by AMP, which also inhibits PP2C, increasing phosphorylation in Thr172. Finally, recent data have revealed that celldeath-inducing like-effector A (CIDEA) forms a complex with the $\beta$ subunit of AMPK, which elicits an ubiquitination-mediated degradation of AMPK, reducing its activity (Fig. 2; Qi et al. 2008). Whatever the mechanism, activated (phosphorylated) AMPK is a counter-regulatory response to avoid ATP depletion in many tissues, leading to a switching off of ATPconsuming processes (such as fatty acid synthesis), while switching on catabolic processes that produce ATP (such as fatty acid $\beta$-oxidation) and restore the AMP:ATP ratio (Ruderman et al. 2003, Kahn et al. 2005, Carling et al. 2008, Lage et al. 2008, Martínez de Morentin et al. 2010a). In the particular case of the lipid metabolism, activated (phosphorylated) AMPK phosphorylates and inhibits ACC (pACC), while activating MCD (Ruderman et al. 2003, Dowell et al. 2005, López et al. 2007, Lage et al. 2008, Martínez de Morentin et al. 2010a). In addition, activated AMPK decreases FAS mRNA expression via a sterol regulatory elementbinding protein-1 (SREBP-1)-dependent mechanism (Zhou et al. 2001, López et al. 2008a,b). Thus, the overall effect of AMPK activation reduces malonyl-CoA and the flux of substrates in the fatty acid biosynthetic pathway.

Evidence gleaned in the last decade has demonstrated that due to the fact that neurons and glial cells need lipid synthesis to sustain their metabolic homeostasis, enzymes of fatty acid metabolism are constitutively expressed in the brain (López et al. 2007). Importantly, AMPK, ACC, CPT1, FAS, and MCD mRNAs and proteins are highly expressed in several metabolically relevant hypothalamic nuclei, such as ARC, DMH, paraventricular (PVH), and VMH (Kim et al. 2002, Sorensen et al. 2002, Minokoshi et al. 2004, López et al. 2006, 2008a,b, 2010, Chakravarthy et al. 2007, Dai et al. 2007). In addition to this morphological evidence, pharmacologic and genetic results have demonstrated that altered levels and activities of these enzymes affect feeding through specific modulation of ARC-derived neuropeptides, namely the orexigenic AGRP and NPY, as well as the anorexigenic POMC and cocaine and amphetamine-regulated transcript (Loftus et al. 2000, Obici et al. 2003, Minokoshi et al. 2004, López et al. 2006, 2008a, Wolfgang et al. 2006, Chakravarthy et al. 2007). Since these impaired fatty acid metabolism altered the hypothalamic pool of either malonyl-CoA (Hu et al. 2003, López et al. 2006, 2008a, 2010, Chakravarthy et al. 2007, Lage et al. 2010) and/or long-chain fatty acids-CoA (LCFA-CoA; Obici et al. 2003, He et al. 2006, Pocai et al. 2006, López et al. 2010), these metabolites have been proposed as signals of nutrient abundance able to modulate feeding. Whether alternative hypothalamic lipid metabolites are involved in feeding control will require further investigation.

\section{Hypothalamic AMPK: a crucial mediator of whole-body energy balance}

Similarly to fatty acid metabolism enzymes, AMPK is expressed in several key hypothalamic nuclei, including ARC, LHA, PVH, and VMH (Minokoshi et al. 2004, López et al. 2008a, 2010). During physiological regulation of feeding, changes of hypothalamic AMPK are critical parts of the adaptive response. Fasting stimulates hypothalamic AMPK, while refeeding inhibits it (Minokoshi et al. 2004, Lage et al. 2008, López et al. 2008a, Vázquez et al. 2008, Martínez de Morentin et al. 2010a). Activation of AMPK in the hypothalamus (by using adenoviruses expressing constitutively active AMPK, AMPK-CA) elicits feeding and body weight gain (Minokoshi et al. 2004). On the other hand, inhibition of hypothalamic AMPK (by using adenoviruses expressing dominant negative AMPK, AMPK-DN) promotes anorexia and weight loss (Minokoshi et al. 2004, López et al. 2008a, 2010). Importantly, as with the variations in the hypothalamic concentration of malonyl-CoA and LCFA-CoA, alterations in hypothalamic AMPK activity are associated with modifications of neuropeptide mRNA levels. Inhibition of hypothalamic AMPK with an AMPK-DN isoform decreases the mRNA expression of AGRP and NPY in the ARC; on the contrary, overexpression of an AMPK$\mathrm{CA}$ isoform elevates the fasting-induced expression of AGRP and NPY in the ARC and also MCH in the LHA (Minokoshi et al. 2004).

Besides the response to starvation, recent evidence has shed light on the central physiological role of hypothalamic AMPK in the regulation of energy homeostasis by integrating peripheral signals with hypothalamic networks. Of note, the effects of fasting and refeeding on hypothalamic AMPK are associated with the changes in circulating nutrients, hormones, and hypothalamic neuropeptides (Table 1 and Fig. 3). AMPK activation in several hypothalamic nuclei such as VMH, ARC, and PVH has a significant part in mediating counter-regulatory responses to acute hypoglycemia, such as attenuated hypoglycemia-induced increases in plasma corticosterone, glucagons, and epinephrine (Han et al. 2005, McCrimmon et al. 2006, Alquier et al. 2007, Cotero \& Routh 2009, Fan et al. 2009), in 


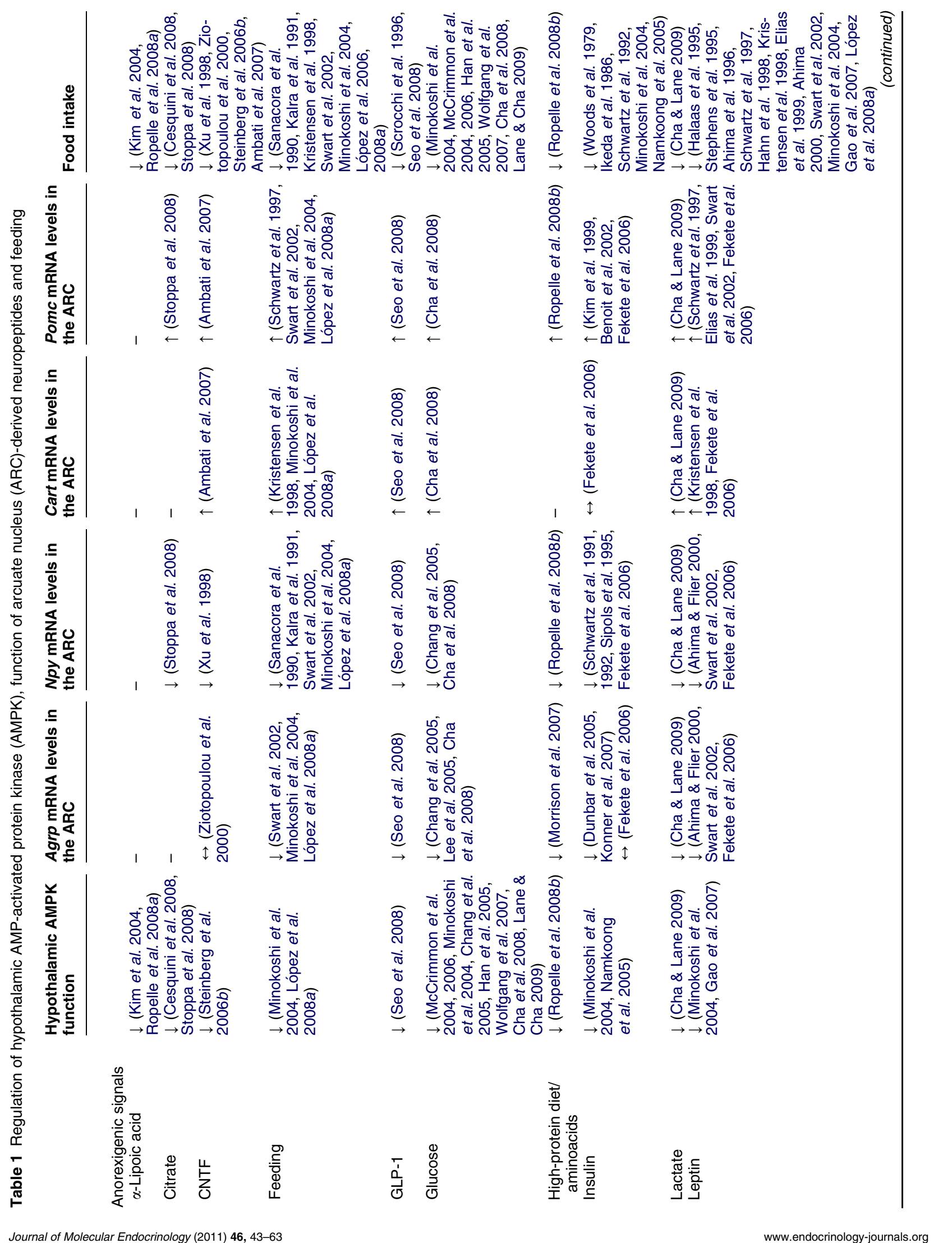




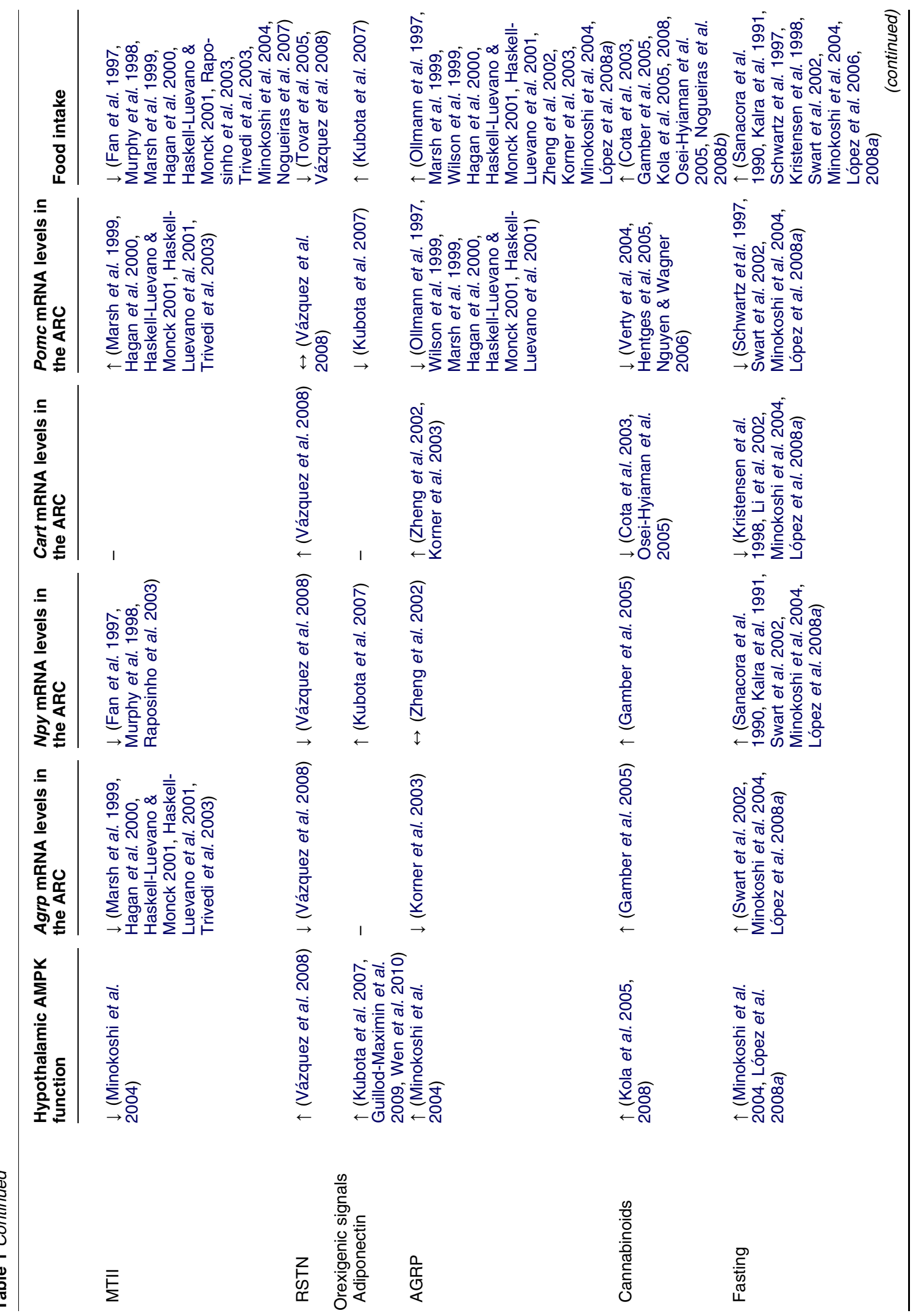




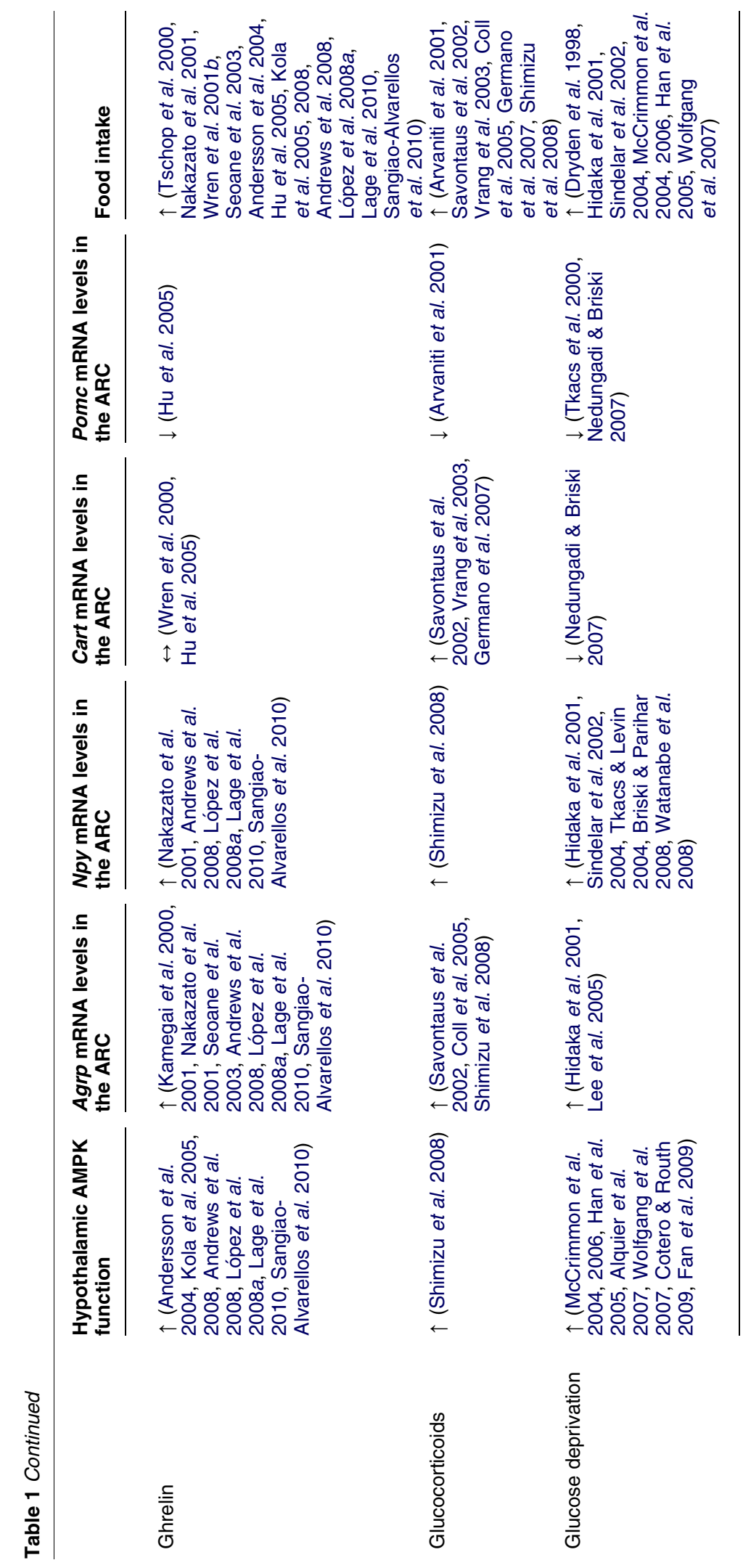




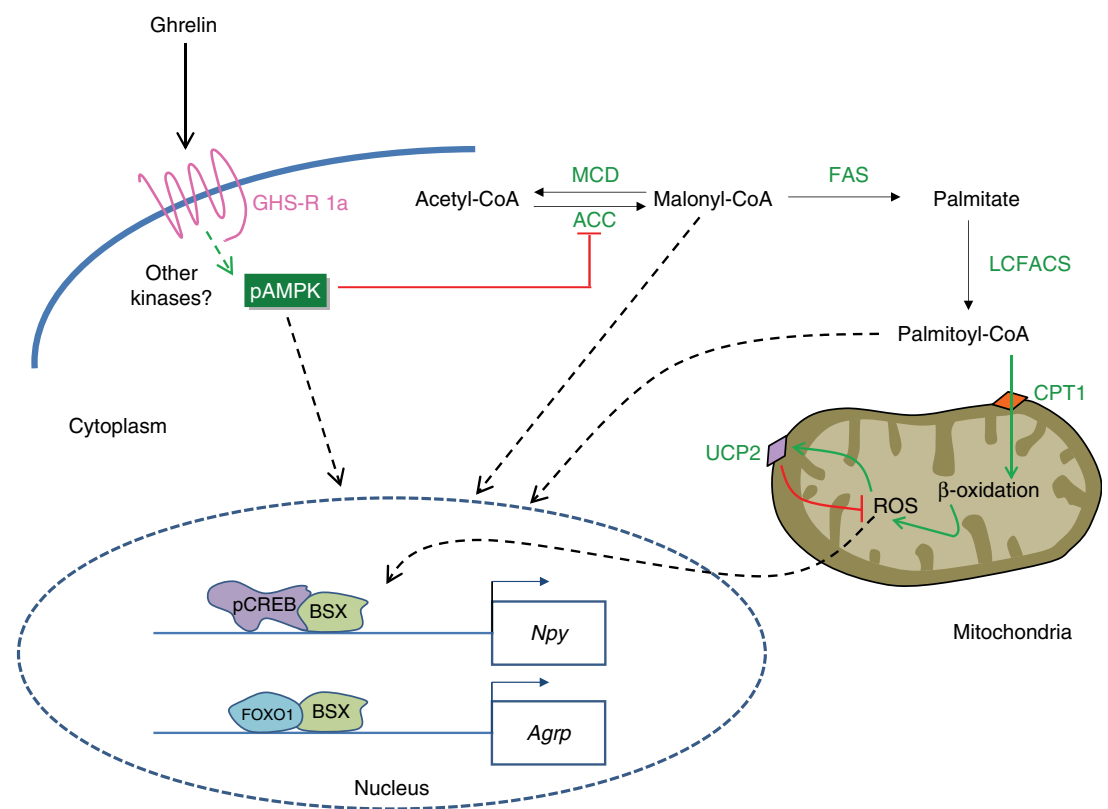

Figure 3 Central ghrelin actions on hypothalamic lipid metabolism and AMPK. Ghrelin, acting on GH secretagogue receptor 1a (GHS-R 1a), regulates hypothalamic AMPactivated protein kinase (AMPK), phosphorylating (pAMPK) and activating it, which in turn phosphorylates and inactivates acetyl-CoA carboxylase (ACC), decreasing the cytoplasmatic pool of malonyl-CoA. The net result of this action is an increase in carnitine palmitoyltransferase 1 (CPT1) activity and then fatty acid oxidation, which promotes the generation of reactive oxygen species (ROS), which are buffered by uncoupling protein 2 (UCP2). This mechanism is critical for ghrelin-induced electric activation of agouti-related peptide/neuropeptide Y (AGRP/NPY) neurons, ghrelin-induced upregulation of Agrp and Npy gene expression in the ARC, and ghrelin-induced feeding. The molecular events connecting the CPT1-ROS-UCP2 axis with the transcription factors (BSX, pCREB and FOXO1) involved in the gene expression of Agrp and Npy remain unclear. Alternatively, a direct interaction of AMPK, malonyl-CoA, palmitoyl-CoA (or other lipid species) with that signaling pathway may be possible. Dotted lines represent indirect or unknown interactions.

hypoglycemia sensing (McCrimmon et al. 2004, Murphy et al. 2009), and glucose production (Yang et al. 2010). In concurrence with these findings, central administration of glucose suppresses AMPK activity in the hypothalamus, decreasing feeding (Minokoshi et al. 2004, Wolfgang et al. 2007, Cha et al. 2008, Lane \& Cha 2009). Metabolites also modulate hypothalamic AMPK function. $\alpha$-Lipoic acid, a cofactor of mitochondrial enzymes with antioxidant and anorectic properties (Kim et al. 2004, Ropelle et al. 2008a), citrate (Cesquini et al. 2008, Stoppa et al. 2008), and lactate (Cha \& Lane 2009) elicit anorexigenic responses associated with inhibition of AMPK, activation of ACC, and subsequent increase in malonyl-CoA. Furthermore, anorectic hormones, such as leptin, insulin, glucagon-like peptide-1 (GLP-1), ciliary neurotrophic factor (CNTF), and melanocortin receptors agonists, including melanotan II (MTII), inhibit hypothalamic AMPK (Andersson et al. 2004, Minokoshi et al. 2004, Steinberg et al. 2006b, Gao et al. 2007, Wolfgang et al. 2007, Seo et al. 2008). In contrast, activation of hypothalamic AMPK is caused by orexigenic signals such as AGRP, adiponectin, cannabinoids, glucocorticoids, and ghrelin (see later; Andersson et al. 2004, Kola et al. 2005, Kubota et al. 2007, Andrews et al. 2008, López et al. 2008a, Shimizu et al. 2008, Lage et al. 2010, Sangiao-Alvarellos et al. 2010, Wen et al. 2010). Resistin (RSTN), despite its anorectic effect, activates hypothalamic AMPK (Vázquez et al. 2008). Finally, current evidence has demonstrated the hypothalamic AMPK mediates thyroid hormone actions on energy balance by controlling the brown adipose tissue (BAT) thermogenic program through activation of the sympathetic nervous system (SNS; López et al. 2010). Thus, in general, it can be stated that hypothalamic AMPK is a genuine element of the energy homeostasis system, as shown in the findings. Interestingly, in spite of the vast evidence linking this kinase to peripheral signals (Table 1), the molecular effects of these interactions have been mainly investigated only for ghrelin, which are summarized below. 


\section{Central ghrelin actions on hypothalamic lipid metabolism and AMPK}

Although the 'classical' pathway involving AGRP/NPY neurons, and more recently BSX-FOXO1-pCREB, has revealed some of the mechanisms underlying the orexigenic effect of ghrelin, it was apparent that some of the key factors implicated in the transduction pathway of the activated GHS-R1a were still missing. Recent data indicate that ghrelin modulates hypothalamic AMPK (Andersson et al. 2004, Kola et al. 2005, 2008, Andrews et al. 2008, López et al. 2008a,b, Lage et al. 2010, Sangiao-Alvarellos et al. 2010). By using a combination of pharmacological, physiological, and genetic approaches, several groups, including ours, have demonstrated that the physiological orexigenic response to ghrelin involves specific AMPK-induced inhibition of fatty acid biosynthesis, which results in decreased hypothalamic levels of malonyl-CoA and increased CPT1 activity (Andrews et al. 2008, López et al. 2008a,b, Lage et al. 2010, Sangiao-Alvarellos et al. 2010). In this context, ghrelin-induced activation of hypothalamic fatty acid oxidation leads to robust changes in hypothalamic mitochondrial respiration and production of ROS, which are buffered by uncoupling protein 2 (UCP2; Andrews et al. 2008). This mechanism is critical for ghrelin-induced electric activation of AGRP/NPY neurons, ghrelin-triggered synaptic plasticity of POMC neurons and ghrelindependent gene transcription events in those cells (Fig. 3). Thus, ghrelin-induced upregulation of Agrp, $N p y, U c p 2, C p t 1$, and nuclear respiratory factor 1 (Nrf1) gene expression is blunted in UCP2 KO mice (Andrews et al. 2008). Finally, recent elegant data from Korbonits and colleagues have also demonstrated that hypothalamic cannabinoids cross talk with the ghrelinAMPK signaling. Food intake is induced through the cannabinoid receptor type 1 (CB1; Pagotto et al. 2006) and stimulation of AMPK (Kola et al. 2005) by both exogenous and endogenous cannabinoids. The occurrence of an intact functional CB1 receptor is needed for ghrelin's effect on AMPK activity and food intake, as shown in CB1 KO animals, as well as using a CB1 antagonist (Kola et al. 2008). These data imply that an intact endocannabinoid-CB1 pathway is essential for the AMPK-mediated ghrelin's orexigenic effect (Kola et al. 2008).

Although these results provide an interesting mechanism, linking ghrelin-induced changes in fatty acid metabolism and neuropeptide expression, one particular caveat remained unresolved: how alterations in mitochondrial function could lead to nuclear transcriptional events. Our group has recently demonstrated that BSX, FOXO1, and pCREB connect ghrelinpromoted activation of hypothalamic fatty acid $\beta$-oxidation in the mitochondria with nuclear Agrp and Npy gene expression in the ARC (Lage et al. 2010). Furthermore, we demonstrate that this association is a physiological gender-independent mechanism modulating feeding. In fact, pharmacological blockage of hypothalamic fatty acid $\beta$-oxidation, by using the specific CPT1 inhibitor etomoxir, blocks the ghrelininduced effect on BSX and subsequently on Agrp and Npy mRNA expression in the ARC of both male and female rats (Lage et al. 2010). Overall, these results indicate that the BSX-FOXO1-pCREB signaling pathway plays a key role in integrating hypothalamic ghrelin actions. Further experiments, using BSX KO mice (Sakkou et al. 2007), are essential to confirm the existence of alternative pathways to BSX linking ghrelin fatty acid metabolism and neuropeptide expression. Actually, taking into account that BSX KO mice exhibit lower fasting-induced response in Agrp and Npy mRNA levels (Sakkou et al. 2007), the involvement of alternative additional transcription factors cannot be excluded.

In addition to its effects on the AMPK-malonyl-CoACPT1 axis, ghrelin decreases FAS expression in a region-specific manner and this effect is AMPK dependent (Fig. 3; López et al. 2008a,b). This particular effect is interesting because of its physiological significance. The transient response to ghrelin is displayed in the fact that malonyl-CoA returns to normal levels only $6 \mathrm{~h}$ after the initial decrease (López et al. 2008a). Although the process decreasing malonyl-CoA levels may be attributed to the termination of ghrelin stimulation of AMPK (and the subsequent ghrelininduced inactivation of ACC by AMPK), recent data also suggest that a direct effect of ghrelin decreasing FAS expression and activity in the VMH may also contribute to this process (López et al. 2008a). Thus, it has been proposed that this effect prevents the decrease in hypothalamic malonyl-CoA in this nucleus (secondary to fasting-induced inactivation of ACC by AMPK) from reaching deleteriously low levels in the context of food deprivation. This action would increase the level of $\beta$-oxidation and in turn could compromise neuronal viability by thwarting lipid biosynthesis and by allowing potentially harmful neuronal fatty acid oxidation during fasting, a condition of low-energy surplus. Supporting this concept, the reduction in FAS levels is not further decreased by prolonged fasting over a period of $48 \mathrm{~h}$ (López et al. 2006, 2008b). This suggests a tightly controlled FAS threshold in hypothalamic neurons, which is mediated by a mechanism involving the transcriptional regulation of SREBP-1 by AMPK (López et al. 2008a,b). In addition, the decrease in FAS after fasting or ghrelin administration is circumscribed to the VMH, where the GHS-R is highly expressed (Bennett et al. 1997, Guan et al. 1997, Tannenbaum et al. 1998, Willesen et al. 1999, Mitchell et al. 2001, Nogueiras et al. 2004, Smith 2005, Zigman et al. 2006, López et al. 
2008a) is appealing. The VMH integrates peripheral signals alongside other hypothalamic nuclei and the brainstem, connected through specific neuronal projections (Tong et al. 2007). Thus, these data indicate that FAS in the VMH may play a role as a sensor of the nutritional state, besides its lipogenic effect (López et al. $2008 a, b)$.

Overall, these data show that hypothalamic fatty acid metabolism plays an integrative role in the short-term orexigenic response to ghrelin. However, the current data have challenged the long-term relevance of this mechanism, and thus its contribution to the increase in body mass and adiposity promoted by chronic central ghrelin administration (Tschop et al. 2000, TheanderCarrillo et al. 2006, Sangiao-Alvarellos et al. 2009). The current data show that chronic central ghrelin administration does not elicit large changes in either AMPK or ACC activities in normal rats, but expressly inhibits FAS expression in the VMH and hypothalamic CPT1 activity (Sangiao-Alvarellos et al. 2010). Bearing in mind that chronic ghrelin treatment exerted a profound orexigenic action and parallel changes in AGRP and NPY expression in the ARC (Sangiao-Alvarellos et al. 2010), we are able to speculate that 1) in long-term altered nutritional conditions, AMPK-induced changes in hypothalamic fatty acid metabolism cannot play a key role in feeding control; in accordance with this hypothesis it has been suggested that hypothalamic fatty acid metabolism could be a regulatory mechanism engineered to maintain energy homeostasis in starvation (Andrews et al. 2008, López et al. 2008a,b) and 2) contrary to short-term ghrelin action, chronic ghrelin inhibits hypothalamic CPT1 activity, which shows that in the long-term setting ghrelin could block hypothalamic $\beta$-oxidation, following the results obtained in the liver after long-term ghrelin treatment (Theander-Carrillo et al. 2006). The physiological significance of this action is uncertain, but it has been hypothesized that it could be a compensatory mechanism to the large orexigenic signal promoted by central hyperghrelinemia (Sangiao-Alvarellos et al. 2010). This concept originates from earlier data showing that pharmacological inhibition and/or genetic ablation of hypothalamic CPT1 (Obici et al. 2003, Pocai et al. 2006, Wolfgang et al. 2006, Wolfgang \& Lane 2008) or overexpression of MCD (He et al. 2006) induces the cytoplasmic accumulation of fatty acyl-CoA concentration and decreases food intake and body weight.

\section{GH-dependent effects of ghrelin on hypothalamic lipid metabolism}

In addition to its role in the modulation of energy homeostasis, ghrelin also controls the secretion of GH, by acting as a powerful GHS in rodents and humans
(Kojima et al. 1999, Masuda et al. 2000, Peino et al. 2000, Takaya et al. 2000). There are several studies highlighting the importance of GH signaling on the effect of ghrelin on metabolism. In spite of data demonstrating that GH-deficient rats show weight gain and adiposity induced by ghrelin (Tschop et al. 2000, Wren et al. 2000, Nakazato et al. 2001, Wren et al. $2001 b)$, i.c.v. ghrelin treatment did not increase food intake in $\mathrm{GH}$ receptor gene-deficient mice (Egecioglu et al. 2006) and ghrelin failed to increase the expression of GHS-R in the ARC of dwarf rats (Nogueiras et al. 2004). Examination of ghrelin's effect on the fatty acid metabolism pathway in the hypothalamus of GH-deficient dwarf rats showed increased pAMPK levels after chronic ghrelin administration, without changes in CPT1 activity (which is decreased in dwarf rats) and no change in FAS mRNA and protein expression (Sangiao-Alvarellos et al. 2010). These data indicate that the actions of ghrelin on hypothalamic fatty acid metabolism are independent of GH and, in contrast to normal rats, chronic ghrelininduced hyperphagia in dwarf rats could be mediated by specific modulation of the lipogenic pathway. It is possible that this effect is due to elevated hypothalamic GHS-R expression in GH deficiency (Nogueiras et al. 2004), but the molecular foundation of the effect is yet to be determined. In this context, it would be critical to assess whether that action is mediated by the canonical BSX-FOXO1-pCREP pathway. Equally intriguing are the results showing that ghrelin-mediated decrease in FAS expression is blunted in the VMH of dwarf rats. As stated earlier, to avert a harmful drop in the levels of malonyl-CoA in the hypothalamus, data have shown that a physiological adaptive mechanism causes ghrelin- and fasting-induced decreases in FAS levels in the VMH (Andrews et al. 2008, López et al. $2008 a, b)$. Since this regulatory mechanism is lost in dwarf rats, it is possible that an accumulation of toxic lipid species and lipotoxicity-associated phenomena, such as ER stress (Hosoi et al. 2008, Zhang et al. 2008, Ozcan et al. 2009, Won et al. 2009, Martínez de Morentin et al. 2010b), might be caused by altered fatty acid fluxes in the hypothalamic neurons, which may be induced from GH-deficiency, thus hindering hypothalamic metabolism in these animals. Further work will be necessary to address these issues. As seen in this evidence, the hypothalamus of dwarf rats displayed decreases in both de novo lipogenesis and $\beta$-oxidation after chronic ghrelin treatment (SangiaoAlvarellos et al. 2010). These results are quite opposite to the observed data in normal rats, where ghrelin decreases both de novo lipogenesis but stimulates $\beta$-oxidation in the hypothalamus (Andersson et al. 2004, Kola et al. 2005, 2008, Andrews et al. 2008, López et al. 2008a, Sangiao-Alvarellos et al. 2010) and suggest that ghrelin actions on hypothalamic fatty 
acid metabolism are $\mathrm{GH}$ independent. Considering the essential role of GH on peripheral lipid metabolism (Maccario et al. 2000, van der Lely et al. 2004, van der Lely 2009), to determine the physiological relevance of these data is difficult. Following this theme, current findings indicate that $\mathrm{GH}$ dependency is not shown in the central ghrelin effects on either adipose or hepatic liver metabolism (Sangiao-Alvarellos et al. 2009).

\section{Central ghrelin actions on hypothalamic CAMKK2}

The ghrelin receptor, a Gq-coupled receptor, increases intracellular $\mathrm{Ca}^{2+}$ via phospholipase $\mathrm{C}$ and protein kinase C induction (Garcia et al. 2001, van der Lely et al. 2004). Since rises in intracellular $\mathrm{Ca}^{2+}$ lead to activation of CAMKK2, an upstream AMPK kinase (Hawley et al. 2005, Woods et al. 2005), which is abundantly expressed in the ARC (Anderson et al. 2008), it has recently been proposed that this interaction could be important for feeding control. Supporting this hypothesis, the CAMKK2 KO mice (CAMKK2 KO) showed reduced expression of AGRP and NPY in the ARC (Anderson et al. 2008). Consistent with this, hypothalamic AMPK activity is also decreased in the CAMKK2 KO mice, which also show resistance to the ghrelin orexigenic effect (Anderson et al. 2008). In keeping with these observations, STO-609, a selective CAMKK2 inhibitor, inhibited NPY expression and reduced food intake and body weight in wild-type animals. Moreover, the loss of CAMKK2 protects mice from high-fat diet (HFD)-induced obesity, insulin resistance, and glucose intolerance (Anderson et al. 2008).

\section{Central ghrelin actions on peripheral lipid metabolism}

In addition to its role as the main modulator of hypothalamic lipid metabolism, recent data have also highlighted the role of ghrelin as a main modulator of peripheral lipid metabolism (Nogueiras et al. 2010). Central administration of ghrelin directly elicits adiposity by the stimulation of the lipogenic program in the white adipose tissue (WAT) in a food intakeindependent manner (Theander-Carrillo et al. 2006, Nogueiras et al. 2007, Sangiao-Alvarellos et al. 2009, Andrews et al. 2010). In particular, central ghrelin administration stimulates AGRP/NPY neurons, which promotes the blockade of the melanocortin receptors 3 and 4 (MC3R and MC4R) and regulation of peripheral lipid metabolism through the SNS (Theander-Carrillo et al. 2006, Nogueiras et al. 2007). As a result of these events, mRNA expression of various fat storagepromoting enzymes such as lipoprotein lipase (LPL), ACC $\alpha$, FAS, and stearoyl-CoA desaturase-1 (SCD1) is induced in WAT; on the other hand, the rate-limiting step in fat oxidation, CPT1, was decreased (Fig. 4; Theander-Carrillo et al. 2006, Sangiao-Alvarellos et al. 2009, Andrews et al. 2010). Opposite expression patterns seen throughout i.c.v. ghrelin treatment were discovered in ghrelin KO mice. This discovery is consistent with this pharmacological data, recognizing the fact that the endogenous ghrelin system is a major factor in the physiological regulation of WAT metabolism (Nogueiras et al. 2010). Specifically, Lpl and Scd1 mRNA expression was decreased in ghrelin KO mice compared with wild-type controls (Theander-Carrillo et al. 2006). Taken as a whole, this evidence indicates that central ghrelin action is of physiological relevance in the control of adipocyte metabolism and indicated

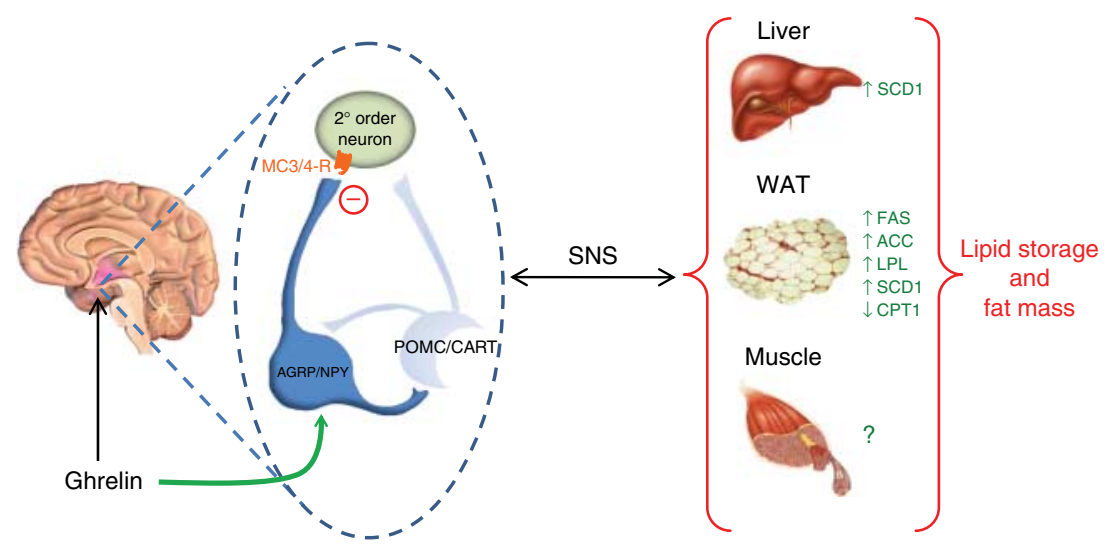

Figure 4 Central ghrelin actions on peripheral lipid metabolism. Ghrelin stimulates agoutirelated peptide/neuropeptide Y (AGRP/NPY) neurons. This action leads to a blockade of the melanocortin receptor 3 and 4 (MC3R and MC4R) by AGRP and subsequent modulation of peripheral lipid metabolism through the sympathetic nervous system (SNS). Blockade of MC3R and MC4R increases lipid storage and adiposity. 
that ghrelin could elicit the processes in the central nervous system in readiness for the ingestion of food (Nogueiras et al. 2010). Interestingly, central ghrelin reduced UCP1 and UCP3 in BAT (Theander-Carrillo et al. 2006), suggesting that, besides increased lipogenesis, decreased thermogenesis and energy expenditure might contribute to adiposity. In this sense, a recent and elegant report form Horvath et al. demonstrated that the feeding-independent lipogenic actions of ghrelin are enhanced in mice lacking UCP2 (UCP2 KO; Andrews et al. 2010). The molecular mechanisms under this effect are not fully understood, but UCP2 KO mice display high expression of lipogenic enzymes, such as FAS, SCD1, and LPL, and decreased expression of CPTla in WAT (Andrews et al. 2010). These data correlate with the higher susceptibility to gain weight in an HFD observed in this model (Joseph et al. 2002), as well as with that well-established UCP2-mediated increase in fatty acid oxidation under fasting (Andrews et al. 2008, Pecqueur et al. 2008, Sheets et al. 2008). These data identify UCP2 as a common factor modulating energy homeostasis at hypothalamic (Andrews et al. 2008) and peripheral level (Andrews et al. 2010). Moreover, they suggest that ghrelin-induced UCP2 expression in WAT may be a protective mechanism to prevent excessive weight gain and obesity. Additional work will be required to address whether the AMPK-malonyl-CoA-CPT1-UCP2 axis is specific to the actions of ghrelin on feeding and peripheral lipogenesis or a common mechanism for hormonal signals modulating both processes, such as leptin (Pocai et al. 2005b, Buettner et al. 2006, 2008), insulin (Obici et al. 2002a,b, Pocai et al. 2005a, Plum et al. 2006, Koch et al. 2008), melanocortins (Nogueiras et al. 2007), RSTN (Vázquez et al. 2008), and GLP-1 (Nogueiras et al. 2009).

\section{GH-dependent effects of ghrelin on peripheral lipid metabolism}

Considering the role of ghrelin as a GHS (Kojima et al. 1999, Masuda et al. 2000, Peino et al. 2000, Takaya et al. 2000), as well as the important actions of GH on peripheral lipid metabolism (Maccario et al. 2000, van der Lely et al. 2004, van der Lely 2009), we have recently examined the effects of chronic central ghrelin administration on peripheral lipid metabolism in dwarf rats. Our results indicate that central chronic ghrelin administration regulates adipose lipid metabolism, mainly in a GH-independent manner, as a result of increased mRNA, protein expression, and activity levels of ACC $\alpha$, FAS, and SCD1, which increased in dwarf rats when compared with normal wild-type rats (Sangiao-Alvarellos et al. 2009). Conversely, central ghrelin regulates hepatic de novo lipogenesis in a
GH-independent manner but fatty acid oxidation in a GH-dependent manner, because CPT1 was inhibited only in normal rats (Sangiao-Alvarellos et al. 2009). Furthermore, and in contrast to the hypothalamus (Andrews et al. 2008, López et al. 2008a,b), we showed that in peripheral tissues the increased ghrelin levels during food deprivation do not mediate the effects of fasting. In these tissues, starvation downregulates the expression of lipogenic enzymes, and activates (in the liver) or downregulates (in WAT) CPT1, which are the opposite effects to those observed after the ghrelin treatment (Sangiao-Alvarellos et al. 2009).

\section{Concluding remarks}

The positives of ensuring accurate regulation of homeostatic systems are complexity and redundancy. Lipid metabolism is a central element, which modulates energy balance downstream the ghrelin signaling pathway. Not only do recent anatomical and pharmacological data demonstrate this, but it is also backed up by current genetic and physiological evidence as well. At the hypothalamic level, the short-term (but not the long-term) orexigenic effect of ghrelin is mediated by AMPK-driven changes in hypothalamic lipid metabolism (ACC, FAS, and CPT1) and UCP2 that subsequently influence neuropeptide gene expression through the transcription factors BSX, FOXO1, and pCREB (Andersson et al. 2004, Kola et al. 2005, 2008, Andrews et al. 2008, López et al. 2008a,b, Lage et al. 2010, Sangiao-Alvarellos et al. 2010). Similarly, central ghrelin also acts by modulating the adipose lipogenic pathway through the SNS in a GH-independent but UCP2dependent manner (Theander-Carrillo et al. 2006, Sangiao-Alvarellos et al. 2009, Andrews et al. 2010).

On the basis of these data, it is tempting to speculate that ghrelin favors energy stores in order to minimize the negative effects on periods of food scarcity (Nogueiras et al. 2010). During fasting, increased ghrelin levels stimulate appetite and facilitates anabolic processes when food becomes available by triggering biological responses that modulate the efficiency of energy storage, i.e. increasing lipogenesis and inducing UCP2 in WAT, which shifts the organism from a negative energy balance state to a neutral energy balance state, avoiding overweight and obesity (Tsubone et al. 2005, Andrews et al. 2008, 2010, López et al. 2008a, Sangiao-Alvarellos et al. 2009, Nogueiras et al. 2010). However, this mechanism, which was primarily designed as a response to fasting, under conditions of HFD (Wortley et al. 2005, Zigman et al. 2005) or GH deficiency (Sangiao-Alvarellos et al. 2009), seems to increase excessively positive energy balance and fat mass, which ultimately may lead to harmful pro-obesogenic and diabetic states. 
Alternatively, a new and crucial link between ghrelin and lipids has been recently revealed by studying ghrelin $O$-acyl transferase (GOAT), the enzyme responsible for ghrelin acylation (Gonzalez et al. 2008, Gutierrez et al. 2008, Yang et al. 2008). Tschop and colleagues have elegantly demonstrated that GOAT is regulated by nutrient availability and depends on specific dietary lipids, such as medium-chain fatty acids, which act as acylation substrates (Kirchner et al. 2009). This evidence links ingested lipids to ghrelin action and suggests that, to obtain optimal nutrient partitioning, the availability of high caloric food is signaled to the hypothalamus through readily absorbable medium-chain fatty acids, originating from the GOAT-ghrelin system working as a nutrient sensor.

Altogether, these data identify the ghrelin-lipid metabolism interaction as a key homeostatic process modulating energy balance. Further work will be necessary to investigate the therapeutic implication of the ghrelin-lipid metabolism partnership for the treatment of obesity and metabolic syndrome.

\section{Declaration of interest}

The authors declare that there is no conflict of interest that could be perceived as prejudicing the impartiality of the review reported.

\section{Funding}

The research leading to these results has received funding from the European Community's Seventh Framework Programme (FP7/20072013) under grant agreements no. 245009 (R N, C D, and M L) and no. 018734 (A V P), Xunta de Galicia (F C: PS07/12; C D: PGIDIT06PXIB208063PR; M L: 10PXIB208164PR), Fondo Investigationes Sanitarias (F C: PI051024 and PI070413; M L: PS09/01880), Ministerio de Educacion y Ciencia (R N: RyC-2008-02219; C D: BFU2008; M L: RyC-2007-00211), Medical Research Council (A V P) and Welcome Trust (AV P). CIBER de Fisiopatología de la Obesidad y Nutrición is an initiative of ISCIII.

\section{References}

Ahima RS 2000 Leptin and the neuroendocrinology of fasting. Frontiers of Hormone Research 26 42-56. (doi:10.1159/000061014)

Ahima RS \& Flier JS 2000 Leptin. Annual Review of Physiology 62 413-437. (doi:10.1146/annurev.physiol.62.1.413)

Ahima RS, Prabakaran D, Mantzoros C, Qu D, Lowell B, Maratos-Flier E \& Flier JS 1996 Role of leptin in the neuroendocrine response to fasting. Nature 382 250-252. (doi:10.1038/382250a0)

Alquier T, Kawashima J, Tsuji Y \& Kahn BB 2007 Role of hypothalamic adenosine $5^{\prime}$-monophosphate-activated protein kinase in the impaired counterregulatory response induced by repetitive neuroglucopenia. Endocrinology 148 1367-1375. (doi:10.1210/en. 2006-1039)

Ambati S, Duan J, Duff E, Choi YH, Hartzell DL, Della-Fera MA \& Baile CA 2007 Gene expression in arcuate nucleus-median eminence of rats treated with leptin or ciliary neurotrophic factor. Biofactors 31 133-144. (doi:10.1002/biof.5520310204)
Anderson KA, Ribar TJ, Lin F, Noeldner PK, Green MF, Muehlbauer MJ, Witters LA, Kemp BE \& Means AR 2008 Hypothalamic CaMKK2 contributes to the regulation of energy balance. Cell Metabolism 7 377-388. (doi:10.1016/j.cmet.2008.02.011)

Andersson U, Filipsson K, Abbott CR, Woods A, Smith K, Bloom SR, Carling D \& Small CJ 2004 AMP-activated protein kinase plays a role in the control of food intake. Journal of Biological Chemistry 279 12005-12008. (doi:10.1074/jbc.C300557200)

Andrews ZB, Liu ZW, Walllingford N, Erion DM, Borok E, Friedman JM, Tschop MH, Shanabrough M, Cline G, Shulman GI et al. 2008 UCP2 mediates ghrelin's action on NPY/AgRP neurons by lowering free radicals. Nature 454 846-851. (doi:10.1038/nature07181)

Andrews ZB, Erion DM, Beiler R, Choi CS, Shulman GI \& Horvath TL 2010 Uncoupling protein-2 decreases the lipogenic actions of ghrelin. Endocrinology 151 2078-2086. (doi:10.1210/en.2009-0850)

Arvaniti K, Huang Q \& Richard D 2001 Effects of leptin and corticosterone on the expression of corticotropin-releasing hormone, agouti-related protein, and proopiomelanocortin in the brain of ob/ob mouse. Neuroendocrinology 73 227-236. (doi:10. 1159/000054639)

Belgardt BF, Husch A, Rother E, Ernst MB, Wunderlich FT, Hampel B, Klockener T, Alessi D, Kloppenburg P \& Bruning JC 2008 PDK1 deficiency in POMC-expressing cells reveals FOXO1-dependent and -independent pathways in control of energy homeostasis and stress response. Cell Metabolism 7 291-301. (doi:10.1016/j.cmet. 2008.01.006)

Bennett PA, Thomas GB, Howard AD, Feighner SD, Van Der Ploeg LH, Smith RG \& Robinson IC 1997 Hypothalamic growth hormone secretagogue-receptor (GHS-R) expression is regulated by growth hormone in the rat. Endocrinology 138 4552-4557. (doi:10.1210/en. 138.11.4552)

Benoit SC, Air EL, Coolen LM, Strauss R, Jackman A, Clegg DJ, Seeley RJ \& Woods SC 2002 The catabolic action of insulin in the brain is mediated by melanocortins. Journal of Neuroscience $\mathbf{2 2}$ 9048-9052.

Bittencourt JC, Presse F, Arias C, Peto C, Vaughan J, Nahon JL, Vale W \& Sawchenko PE 1992 The melanin-concentrating hormone system of the rat brain: an immuno- and hybridization histochemical characterization. Journal of Comparative Neurology 319 218-245. (doi:10.1002/cne.903190204)

Briski KP \& Parihar M 2008 Effects of orchidectomy on adaptation of arcuate neuropeptide $\mathrm{Y}$, proopiomelanocortin, and cocaine- and amphetamine-related transcript gene profiles to recurring insulininduced hypoglycemia in the male rat. Neuropeptides 42 585-591. (doi:10.1016/j.npep.2008.09.001)

Broberger C, de Lecea L, Sutcliffe JG \& Hokfelt T 1998 Hypocretin/ orexin- and melanin-concentrating hormone-expressing cells form distinct populations in the rodent lateral hypothalamus: relationship to the neuropeptide $Y$ and agouti gene-related protein systems. Journal of Comparative Neurology 402 460-474. (doi:10.1002/ (SICI) 1096-9861 (19981228) 402:4<460::AID-CNE3 > 3.0.CO;2-S)

Buettner C, Pocai A, Muse ED, Etgen AM, Myers MG Jr \& Rossetti L 2006 Critical role of STAT3 in leptin's metabolic actions. Cell Metabolism 4 49-60. (doi:10.1016/j.cmet.2006.04.014)

Buettner C, Muse ED, Cheng A, Chen L, Scherer T, Pocai A, Su K, Cheng B, Li X, Harvey-White J et al. 2008 Leptin controls adipose tissue lipogenesis via central, STAT3-independent mechanisms. Nature Medicine 14 667-675. (doi:10.1038/nm1775)

Carling D, Sanders MJ \& Woods A 2008 The regulation of AMPactivated protein kinase by upstream kinases. International Journal of Obesity 32 (Supplement 4) S55-S59. (doi:10.1038/ijo. 2008.124)

Cesquini M, Stoppa GR, Prada PO, Torsoni AS, Romanatto T, Souza A, Saad MJ, Velloso LA \& Torsoni MA 2008 Citrate diminishes hypothalamic acetyl-CoA carboxylase phosphorylation and modulates satiety signals and hepatic mechanisms involved in glucose homeostasis in rats. Life Sciences 82 1262-1271. (doi:10. 1016/j.lfs.2008.04.015) 
Cha SH \& Lane MD 2009 Central lactate metabolism suppresses food intake via the hypothalamic AMP kinase/malonyl-CoA signaling pathway. Biochemical and Biophysical Research Communications 386 212-216. (doi:10.1016/j.bbrc.2009.06.017)

Cha SH, Wolfgang M, Tokutake Y, Chohnan S \& Lane MD 2008 Differential effects of central fructose and glucose on hypothalamic malonyl-CoA and food intake. PNAS 105 16871-16875. (doi:10. 1073 /pnas.0809255105)

Chakravarthy MV, Zhu Y, López M, Yin L, Wozniak DW, Coleman T, Hu Z, Wolfgang M, Vidal-Puig A, Lane MD et al. 2007 Brain fatty acid synthase activates PPAR- $\alpha$ to maintain energy homeostasis. Journal of Clinical Investigation 117 2539-2552. (doi:10.1172/JCI31183)

Chang GQ, Karatayev O, Davydova Z, Wortley K \& Leibowitz SF 2005 Glucose injection reduces neuropeptide $\mathrm{Y}$ and agouti-related protein expression in the arcuate nucleus: a possible physiological role in eating behavior. Brain Research. Molecular Brain Research 135 69-80. (doi:10.1016/j.molbrainres.2004.12.017)

Chen HY, Trumbauer ME, Chen AS, Weingarth DT, Adams JR, Frazier EG, Shen Z, Marsh DJ, Feighner SD, Guan XM et al. 2004 Orexigenic action of peripheral ghrelin is mediated by neuropeptide Y (NPY) and agouti-related protein (AgRP). Endocrinology 145 2607-2612. (doi:10.1210/en.2003-1596)

Coll AP, Challis BG, López M, Piper S, Yeo GS \& O’Rahilly S 2005 Proopiomelanocortin-deficient mice are hypersensitive to the adverse metabolic effects of glucocorticoids. Diabetes $\mathbf{5 4}$ 2269-2276. (doi:10.2337/diabetes.54.8.2269)

Costanzo-Garvey DL, Pfluger PT, Dougherty MK, Stock JL, Boehm M, Chaika O, Fernandez MR, Fisher K, Kortum RL, Hong EG et al. 2009 KSR2 is an essential regulator of AMP kinase, energy expenditure, and insulin sensitivity. Cell Metabolism 10 366-378. (doi:10.1016/ j.cmet.2009.09.010)

Cota D, Marsicano G, Tschop M, Grubler Y, Flachskamm C, Schubert M, Auer D, Yassouridis A, Thone-Reineke C, Ortmann S et al. 2003 The endogenous cannabinoid system affects energy balance via central orexigenic drive and peripheral lipogenesis. Journal of Clinical Investigation 112 423-431. (doi:10.1172/JCI200317725)

Cotero VE \& Routh VH 2009 Insulin blunts the response of glucoseexcited neurons in the ventrolateral-ventromedial hypothalamic nucleus to decreased glucose. American Journal of Physiology. Endocrinology and Metabolism 296 E1101-E1109. (doi:10.1152/ ajpendo.90932.2008)

Cowley MA, Smith RG, Diano S, Tschop M, Pronchuk N, Grove KL, Strasburger CJ, Bidlingmaier M, Esterman M, Heiman ML et al. 2003 The distribution and mechanism of action of ghrelin in the CNS demonstrates a novel hypothalamic circuit regulating energy homeostasis. Neuron 37 649-661. (doi:10.1016/S08966273(03)00063-1)

Cummings DE, Purnell JQ, Frayo RS, Schmidova K, Wisse BE \& Weigle DS 2001 A preprandial rise in plasma ghrelin levels suggests a role in meal initiation in humans. Diabetes 50 1714-1719. (doi:10.2337/ diabetes.50.8.1714)

Cummings DE, Clement K, Purnell JQ, Vaisse C, Foster KE, Frayo RS, Schwartz MW, Basdevant A \& Weigle DS 2002 Elevated plasma ghrelin levels in Prader-Willi syndrome. Nature Medicine 8 643-644. (doi:10.1038/nm0702-643)

Dai Y, Wolfgang MJ, Cha SH \& Lane MD 2007 Localization and effect of ectopic expression of CPT1c in CNS feeding centers. Biochemical and Biophysical Research Communications 359 469-474. (doi:10.1016/ j.bbrc.2007.05.161)

Dowell P, Hu Z \& Lane MD 2005 Monitoring energy balance: metabolites of fatty acid synthesis as hypothalamic sensors. Annual Review of Biochemistry 74 515-534. (doi:10.1146/annurev.biochem. 73.011303.074027)

Drazen DL, Vahl TP, D'Alessio DA, Seeley RJ \& Woods SC 2006 Effects of a fixed meal pattern on ghrelin secretion: evidence for a learned response independent of nutrient status. Endocrinology 147 23-30. (doi:10.1210/en.2005-0973)
Dryden S, Pickavance L, Henderson L \& Williams G 1998 Hyperphagia induced by hypoglycemia in rats is independent of leptin and hypothalamic neuropeptide Y (NPY). Peptides 19 1549-1555. (doi:10.1016/S0196-9781(98)00106-5)

Dunbar J, Lapanowski K, Barnes M \& Rafols J 2005 Hypothalamic agouti-related protein immunoreactivity in food-restricted, obese, and insulin-treated animals: evidence for glia cell localization. Experimental Neurology 191 184-192. (doi:10.1016/j.expneurol.2004. 09.002)

Egecioglu E, Bjursell M, Ljungberg A, Dickson SL, Kopchick JJ, Bergstrom G, Svensson L, Oscarsson J, Tornell J \& Bohlooly Y 2006 Growth hormone receptor deficiency results in blunted ghrelin feeding response, obesity, and hypolipidemia in mice. American Journal of Physiology. Endocrinology and Metabolism 290 E317-E325. (doi:10.1152/ajpendo.00181.2005)

Elias CF, Saper CB, Maratos-Flier E, Tritos NA, Lee C, Kelly J, Tatro JB, Hoffman GE, Ollmann MM, Barsh GS et al. 1998 Chemically defined projections linking the mediobasal hypothalamus and the lateral hypothalamic area. Journal of Comparative Neurology $\mathbf{4 0 2}$ 442-459. (doi:10.1002/(SICI) 1096-9861 (19981228) 402:4<442:: AID-CNE2 > 3.0.CO;2-R)

Elias CF, Aschkenasi C, Lee C, Kelly J, Ahima RS, Bjorbaek C, Flier JS, Saper CB \& Elmquist JK 1999 Leptin differentially regulates NPY and POMC neurons projecting to the lateral hypothalamic area. Neuron 23 775-786. (doi:10.1016/S0896-6273(01)80035-0)

Ernst MB, Wunderlich CM, Hess S, Paehler M, Mesaros A, Koralov SB, Kleinridders A, Husch A, Munzberg H, Hampel B et al. 2009 Enhanced Stat3 activation in POMC neurons provokes negative feedback inhibition of leptin and insulin signaling in obesity. Journal of Neuroscience 29 11582-11593. (doi:10.1523/JNEUROSCI. 5712-08.2009)

Fan W, Boston BA, Kesterson RA, Hruby VJ \& Cone RD 1997 Role of melanocortinergic neurons in feeding and the agouti obesity syndrome. Nature 385 165-168. (doi:10.1038/385165a0)

Fan X, Ding Y, Brown S, Zhou L, Shaw M, Vella MC, Cheng H, McNay EC, Sherwin RS \& McCrimmon RJ 2009 Hypothalamic AMPactivated protein kinase activation with AICAR amplifies counterregulatory responses to hypoglycemia in a rodent model of type 1 diabetes. American Journal of Physiology. Regulatory, Integrative and Comparative Physiology 296 R1702-R1708. (doi:10.1152/ajpregu. 90600.2008)

Fekete C, Singru PS, Sanchez E, Sarkar S, Christoffolete MA, Riberio RS, Rand WM, Emerson CH, Bianco AC \& Lechan RM 2006 Differential effects of central leptin, insulin, or glucose administration during fasting on the hypothalamic-pituitary-thyroid axis and feeding-related neurons in the arcuate nucleus. Endocrinology 147 520-529. (doi:10.1210/en.2005-0956)

Foster-Schubert KE \& Cummings DE 2006 Emerging therapeutic strategies for obesity. Endocrine Reviews 27 779-793. (doi:10.1210/er. 2006-0041)

Gamber KM, Macarthur H \& Westfall TC 2005 Cannabinoids augment the release of neuropeptide $\mathrm{Y}$ in the rat hypothalamus. Neuropharmacology 49 646-652. (doi:10.1016/j.neuropharm.2005. 04.017)

Gao S, Kinzig KP, Aja S, Scott KA, Keung W, Kelly S, Strynadka K, Chohnan S, Smith WW, Tamashiro KL et al. 2007 Leptin activates hypothalamic acetyl-CoA carboxylase to inhibit food intake. PNAS 104 17358-17363. (doi:10.1073/pnas.0708385104)

Garcia A, Alvarez CV, Smith RG \& Dieguez C 2001 Regulation of pit-1 expression by ghrelin and ghrp-6 through the GH secretagogue receptor. Molecular Endocrinology 15 1484-1495. (doi:10.1210/me. 15.9.1484)

Germano CM, de Castro M, Rorato R, Laguna MT, Antunes-Rodrigues J, Elias CF \& Elias LL 2007 Time course effects of adrenalectomy and food intake on cocaine- and amphetamine-regulated transcript expression in the hypothalamus. Brain Research 1166 55-64. (doi:10. 1016/j.brainres.2007.05.077) 
Gonzalez CR, Vazquez MJ, Lopez M \& Dieguez C 2008 Influence of chronic undernutrition and leptin on GOAT mRNA levels in rat stomach mucosa. Journal of Molecular Endocrinology 41 415-421. (doi:10.1677/JME-08-0102)

Guan XM, Yu H, Palyha OC, McKee KK, Feighner SD, Sirinathsinghji DJ, Smith RG, Van Der Ploeg LH \& Howard AD 1997 Distribution of mRNA encoding the growth hormone secretagogue receptor in brain and peripheral tissues. Brain Research. Molecular Brain Research 48 23-29. (doi:10.1016/S0169-328X(97)00071-5)

Guillod-Maximin E, Roy AF, Vacher CM, Aubourg A, Bailleux V, Lorsignol A, Penicaud L, Parquet M \& Taouis M 2009 Adiponectin receptors are expressed in hypothalamus and colocalized with proopiomelanocortin and neuropeptide $\mathrm{Y}$ in rodent arcuate neurons,. Journal of Endocrinology 200 93-105. (doi:10.1677/JOE-080348)

Gutierrez JA, Solenberg PJ, Perkins DR, Willency JA, Knierman MD, Jin Z, Witcher DR, Luo S, Onyia JE \& Hale JE 2008 Ghrelin octanoylation mediated by an orphan lipid transferase. PNAS 105 6320-6325. (doi:10.1073/pnas.0800708105)

Hagan MM, Rushing PA, Pritchard LM, Schwartz MW, Strack AM, Van Der Ploeg LH, Woods SC \& Seeley RJ 2000 Long-term orexigenic effects of AgRP-(83-132) involve mechanisms other than melanocortin receptor blockade. American Journal of Physiology. Regulatory, Integrative and Comparative Physiology 279 R47-R52.

Hahn TM, Breininger JF, Baskin DG \& Schwartz MW 1998 Coexpression of Agrp and NPY in fasting-activated hypothalamic neurons. Nature Neuroscience 1 271-272. (doi:10.1038/1082)

Halaas JL, Gajiwala KS, Maffei M, Cohen SL, Chait BT, Rabinowitz D, Lallone RL, Burley SK \& Friedman JM 1995 Weight-reducing effects of the plasma protein encoded by the obese gene. Science $\mathbf{2 6 9}$ 543-546. (doi:10.1126/science.7624777)

Han SM, Namkoong C, Jang PG, Park IS, Hong SW, Katakami H, Chun S, Kim SW, Park JY, Lee KU et al. 2005 Hypothalamic AMP-activated protein kinase mediates counter-regulatory responses to hypoglycaemia in rats. Diabetologia 48 2170-2178. (doi:10.1007/s00125-0051913-1)

Haskell-Luevano C \& Monck EK 2001 Agouti-related protein functions as an inverse agonist at a constitutively active brain melanocortin-4 receptor. Regulatory Peptides 99 1-7. (doi:10.1016/S0167-0115(01) 00234-8)

Haskell-Luevano C, Cone RD, Monck EK \& Wan YP 2001 Structure activity studies of the melanocortin- 4 receptor by in vitro mutagenesis: identification of agouti-related protein (AGRP), melanocortin agonist and synthetic peptide antagonist interaction determinants. Biochemistry 40 6164-6179. (doi:10.1021/bi010025q)

Hawley SA, Pan DA, Mustard KJ, Ross L, Bain J, Edelman AM, Frenguelli BG \& Hardie DG 2005 Calmodulin-dependent protein kinase kinase- $\beta$ is an alternative upstream kinase for AMPactivated protein kinase. Cell Metabolism 2 9-19. (doi:10.1016/j. cmet.2005.05.009)

He W, Lam TK, Obici S \& Rossetti L 2006 Molecular disruption of hypothalamic nutrient sensing induces obesity. Nature Neuroscience $\mathbf{9}$ 227-233. (doi:10.1038/nn1626)

Hentges ST, Low MJ \& Williams JT 2005 Differential regulation of synaptic inputs by constitutively released endocannabinoids and exogenous cannabinoids. Journal of Neuroscience 25 9746-9751. (doi:10.1523/JNEUROSCI.2769-05.2005)

Hidaka S, Yoshimatsu H, Kondou S, Oka K, Tsuruta Y, Sakino H, Itateyama E, Noguchi H, Himeno K, Okamoto K et al. 2001 Hypoleptinemia, but not hypoinsulinemia, induces hyperphagia in streptozotocin-induced diabetic rats. Journal of Neurochemistry $\mathbf{7 7}$ 993-1000. (doi:10.1046/j.1471-4159.2001.00317.x)

Holst B, Cygankiewicz A, Halkjar JT, Ankersen M \& Schwartz TW 2003 High constitutive signaling of the ghrelin receptor-identification of a potent inverse agonist. Molecular Endocrinology 17 2201-2210. (doi:10.1210/me.2003-0069)

Horvath TL, Diano S \& van den Pol AN 1999 Synaptic interaction between hypocretin (orexin) and neuropeptide Y cells in the rodent and primate hypothalamus: a novel circuit implicated in metabolic and endocrine regulations. Journal of Neuroscience 19 1072-1087.

Hosoi T, Sasaki M, Miyahara T, Hashimoto C, Matsuo S, Yoshii M \& Ozawa K 2008 Endoplasmic reticulum stress induces leptin resistance. Molecular Pharmacology 74 1610-1619. (doi:10.1124/mol. 108.050070)

Hu Z, Cha SH, Chohnan S \& Lane MD 2003 Hypothalamic malonylCoA as a mediator of feeding behavior. PNAS 100 12624-12629. (doi:10.1073/pnas.1834402100)

Hu Z, Cha SH, van Haasteren G, Wang J \& Lane MD 2005 Effect of centrally administered C75, a fatty acid synthase inhibitor, on ghrelin secretion and its downstream effects. PNAS 102 3972-3977. (doi:10.1073/pnas.0500619102)

Ikeda H, West DB, Pustek JJ, Figlewicz DP, Greenwood MR, Porte D Jr \& Woods SC 1986 Intraventricular insulin reduces food intake and body weight of lean but not obese Zucker rats. Appetite 7 381-386.

Joseph JW, Koshkin V, Zhang CY, Wang J, Lowell BB, Chan CB \& Wheeler MB 2002 Uncoupling protein 2 knockout mice have enhanced insulin secretory capacity after a high-fat diet. Diabetes $\mathbf{5 1}$ 3211-3219.

Kahn BB, Alquier T, Carling D \& Hardie DG 2005 AMP-activated protein kinase: ancient energy gauge provides clues to modern understanding of metabolism. Cell Metabolism 1 15-25. (doi:10. 1016/j.cmet.2004.12.003)

Kalra SP, Dube MG, Sahu A, Phelps CP \& Kalra PS 1991 Neuropeptide $\mathrm{Y}$ secretion increases in the paraventricular nucleus in association with increased appetite for food. PNAS 88 10931-10935. (doi:10. 1073/pnas.88.23.10931)

Kamegai J, Tamura H, Shimizu T, Ishii S, Sugihara H \& Wakabayashi I 2000 Central effect of ghrelin, an endogenous growth hormone secretagogue, on hypothalamic peptide gene expression. Endocrinology 141 4797-4800. (doi:10.1210/en.141.12.4797)

Kamegai J, Tamura H, Shimizu T, Ishii S, Sugihara H \& Wakabayashi I 2001 Chronic central infusion of ghrelin increases hypothalamic neuropeptide $\mathrm{Y}$ and agouti-related protein mRNA levels and body weight in rats. Diabetes 50 2438-2443. (doi:10.2337/diabetes.50.11. 2438)

Kim EM, Grace MK, Welch CC, Billington CJ \& Levine AS 1999 STZinduced diabetes decreases and insulin normalizes POMC mRNA in arcuate nucleus and pituitary in rats. American Journal of Physiology 276 R1320-R1326.

Kim EK, Miller I, Landree LE, Borisy-Rudin FF, Brown P, Tihan T, Townsend CA, Witters LA, Moran TH, Kuhajda FP et al. 2002 Expression of FAS within hypothalamic neurons: a model for decreased food intake after C75 treatment. American Journal of Physiology. Endocrinology and Metabolism 283 E867-E879.

Kim MS, Park JY, Namkoong C, Jang PG, Ryu JW, Song HS, Yun JY, Namgoong IS, Ha J, Park IS et al. 2004 Anti-obesity effects of $\alpha$-lipoic acid mediated by suppression of hypothalamic AMP-activated protein kinase. Nature Medicine 10 727-733. (doi:10.1038/nm1061)

Kim MS, Pak YK, Jang PG, Namkoong C, Choi YS, Won JC, Kim KS, Kim SW, Kim HS, Park JY et al. 2006 Role of hypothalamic Foxol in the regulation of food intake and energy homeostasis. Nature Neuroscience 9 901-906. (doi:10.1038/nn1731)

Kirchner H, Gutierrez JA, Solenberg PJ, Pfluger PT, Czyzyk TA, Willency JA, Schurmann A, Joost HG, Jandacek RJ, Hale JE et al. 2009 GOAT links dietary lipids with the endocrine control of energy balance. Nature Medicine 15 741-745. (doi:10.1038/nm.1997)

Kitamura T, Feng Y, Ido KY, Chua SC, Xu AW, Barsh GS, Rossetti L \& Accili D 2006 Forkhead protein FoxO1 mediates Agrp-dependent effects of leptin on food intake. Nature Medicine 12 534-540. (doi:10. 1038/nm1392)

Koch L, Wunderlich FT, Seibler J, Konner AC, Hampel B, Irlenbusch S, Brabant G, Kahn CR, Schwenk F \& Bruning JC 2008 Central insulin action regulates peripheral glucose and fat metabolism in mice. Journal of Clinical Investigation 118 2132-2147. (doi:10.1172/ JCI31073) 
Kojima M, Hosoda H, Date Y, Nakazato M, Matsuo H \& Kangawa K 1999 Ghrelin is a growth-hormone-releasing acylated peptide from stomach. Nature 402 656-660. (doi:10.1038/45230)

Kola B, Hubina E, Tucci SA, Kirkham TC, Garcia EA, Mitchell SE, Williams LM, Hawley SA, Hardie DG, Grossman AB et al. 2005 Cannabinoids and ghrelin have both central and peripheral metabolic and cardiac effects via AMP-activated protein kinase. Journal of Biological Chemistry 280 25196-25201. (doi:10.1074/jbc. C500175200)

Kola B, Farkas I, Christ-Crain M, Wittmann G, Lolli F, Amin F, Harvey-White J, Liposits Z, Kunos G, Grossman AB et al. 2008 The orexigenic effect of ghrelin is mediated through central activation of the endogenous cannabinoid system. PLoS ONE 3 e1797. (doi:10. 1371/journal.pone.0001797)

Konner AC, Janoschek R, Plum L, Jordan SD, Rother E, Ma X, Xu C, Enriori P, Hampel B, Barsh GS et al. 2007 Insulin action in AgRP-expressing neurons is required for suppression of hepatic glucose production. Cell Metabolism 5 438-449. (doi:10.1016/j.cmet. 2007.05.004)

Korner J, Wissig S, Kim A, Conwell IM \& Wardlaw SL 2003 Effects of agouti-related protein on metabolism and hypothalamic neuropeptide gene expression. Journal of Neuroendocrinology 15 1116-1121. (doi:10.1111/j.1365-2826.2003.01113.x)

Kristensen P, Judge ME, Thim L, Ribel U, Christjansen KN, Wulff BS, Clausen JT, Jensen PB, Madsen OD, Vrang N et al. 1998

Hypothalamic CART is a new anorectic peptide regulated by leptin. Nature 393 72-76. (doi:10.1038/29993)

Kubota N, Yano W, Kubota T, Yamauchi T, Itoh S, Kumagai H, Kozono H, Takamoto I, Okamoto S, Shiuchi T et al. 2007 Adiponectin stimulates AMP-activated protein kinase in the hypothalamus and increases food intake. Cell Metabolism 6 55-68. (doi:10.1016/j.cmet. 2007.06.003)

Lage R, Diéguez C, Vidal-Puig A \& López M 2008 AMPK: a metabolic gauge regulating whole-body energy homeostasis. Trends in Molecular Medicine 14 539-549. (doi:10.1016/j.molmed. 2008.09.007)

Lage R, Vázquez MJ, Varela L, Saha AK, Vidal-Puig A, Nogueiras R, Diéguez C \& López M 2010 Ghrelin effects on neuropeptides in the rat hypothalamus depend on fatty acid metabolism actions on BSX but not on gender. FASEB Journal 24 2670-2679. (doi:10.1096/fj.09150672)

Lane MD \& Cha SH 2009 Effect of glucose and fructose on food intake via malonyl-CoA signaling in the brain. Biochemical and Biophysical Research Communications 382 1-5. (doi:10.1016/j.bbrc. 2009.02.145)

de Lecea L, Kilduff TS, Peyron C, Gao X, Foye PE, Danielson PE, Fukuhara C, Battenberg EL, Gautvik VT, Bartlett FS et al. 1998 The hypocretins: hypothalamus-specific peptides with neuroexcitatory activity. PNAS 95 322-327. (doi:10.1073/pnas.95.1.322)

Lee K, Li B, Xi X, Suh Y \& Martin RJ 2005 Role of neuronal energy status in the regulation of adenosine $5^{\prime}$-monophosphate-activated protein kinase, orexigenic neuropeptides expression, and feeding behavior. Endocrinology 146 3-10. (doi:10.1210/en.2004-0968)

Lee GH, Kim HK, Chae SW, Kim DS, Ha KC, Cuddy M, Kress C, Reed JC, Kim HR \& Chae HJ 2007 Bax inhibitor-1 regulates endoplasmic reticulum stress-associated reactive oxygen species and heme oxygenase-1 expression. Journal of Biological Chemistry 282 21618-21628. (doi:10.1074/jbc.M700053200)

van der Lely AJ 2009 Ghrelin and new metabolic frontiers. Hormone Research 71 (Supplement 1) 129-133. (doi:10.1159/000178055)

van der Lely AJ, Tschop M, Heiman ML \& Ghigo E 2004 Biological, physiological, pathophysiological, and pharmacological aspects of ghrelin. Endocrine Reviews 25 426-457. (doi:10.1210/er.2002-0029)

Li HY, Hwang HW \& Hu YH 2002 Functional characterizations of cocaine- and amphetamine-regulated transcript mRNA expression in rat hypothalamus. Neuroscience Letters 323 203-206. (doi:10.1016/ S0304-3940(02)00151-9)
Loftus TM, Jaworsky DE, Frehywot GL, Townsend CA, Ronnett GV, Lane MD \& Kuhajda FP 2000 Reduced food intake and body weight in mice treated with fatty acid synthase inhibitors. Science $\mathbf{2 8 8}$ 2379-2381. (doi:10.1126/science.288.5475.2379)

López M, Lelliott CJ, Tovar S, Kimber W, Gallego R, Virtue S, Blount M, Vázquez MJ, Finer N, Powles T et al. 2006 Tamoxifen-induced anorexia is associated with fatty acid synthase inhibition in the ventromedial nucleus of the hypothalamus and accumulation of malonyl-CoA. Diabetes 55 1327-1336. (doi:10.2337/db05-1356)

López M, Lelliott CJ \& Vidal-Puig A 2007 Hypothalamic fatty acid metabolism: a housekeeping pathway that regulates food intake. BioEssays 29 248-261. (doi:10.1002/bies.20539)

López M, Lage R, Saha AK, Pérez-Tilve D, Vázquez MJ, Varela L, Sangiao-Alvarellos S, Tovar S, Raghay K, Rodríguez-Cuenca S et al. $2008 a$ Hypothalamic fatty acid metabolism mediates the orexigenic action of ghrelin. Cell Metabolism 7 389-399. (doi:10.1016/j.cmet. 2008.03.006)

López M, Saha AK, Diéguez C \& Vidal-Puig A $2008 b$ The AMPK-malonyl-CoA-CPT1 axis in the control of hypothalamic neuronal function - reply. Cell Metabolism 8 176. (doi:10.1016/ j.cmet.2008.08.003)

López M, Varela L, Vázquez MJ, Rodríguez-Cuenca S, González CR, Velagapudi VR, Morgan DA, Schoenmakers E, Agassandian K, Lage $\mathrm{R}$ et al. 2010 Hypothalamic AMPK and fatty acid metabolism mediate thyroid regulation of energy balance. Nature Medicine 16 1001-1008. (doi:10.1038/nm.2207)

Maccario M, Grottoli S, Procopio M, Oleandri SE, Rossetto R, Gauna C, Arvat E \& Ghigo E 2000 The GH/IGF-I axis in obesity: influence of neuro-endocrine and metabolic factors. International Journal of Obesity and Related Metabolic Disorders 24 (Supplement 2) S96-S99.

Marsh DJ, Hollopeter G, Huszar D, Laufer R, Yagaloff KA, Fisher SL, Burn P \& Palmiter RD 1999 Response of melanocortin-4 receptordeficient mice to anorectic and orexigenic peptides. Nature Genetics 21 119-122. (doi:10.1038/5070)

Martínez de Morentin PB, González CR \& López M 2010a AMP-activated protein kinase: 'a cup of tea' against cholesterol-induced neurotoxicity. Journal of Pathology 222 329-334. (doi:10.1002/path.2778)

Martínez de Morentin PB, Varela L, Ferno J, Nogueiras R, Diéguez C \& López M 2010b Hypothalamic lipotoxicity and the metabolic syndrome. Biochimica et Biophysica Acta 1801 350-361. (doi:10.1016/ j.bbalip.2009.09.016)

Masuda Y, Tanaka T, Inomata N, Ohnuma N, Tanaka S, Itoh Z, Hosoda H, Kojima M \& Kangawa K 2000 Ghrelin stimulates gastric acid secretion and motility in rats. Biochemical and Biophysical Research Communications 276 905-908. (doi:10.1006/bbrc.2000.3568)

McCrimmon RJ, Fan X, Ding Y, Zhu W, Jacob RJ \& Sherwin RS 2004 Potential role for AMP-activated protein kinase in hypoglycemia sensing in the ventromedial hypothalamus. Diabetes 53 1953-1958. (doi:10.2337/diabetes.53.8.1953)

McCrimmon RJ, Fan X, Cheng H, McNay E, Chan O, Shaw M, Ding Y, Zhu W \& Sherwin RS 2006 Activation of AMP-activated protein kinase within the ventromedial hypothalamus amplifies counterregulatory hormone responses in rats with defective counterregulation. Diabetes 55 1755-1760. (doi:10.2337/db05-1359)

Medina-Gomez G, Yetukuri L, Velagapudi V, Campbell M, Blount M, Jimenez-Linan M, Ros M, Oresic M \& Vidal-Puig A 2009 Adaptation and failure of pancreatic $\beta$ cells in murine models with different degrees of metabolic syndrome. Disease Models and Mechanisms 2 582-592. (doi:10.1242/dmm.003251)

Minokoshi Y, Alquier T, Furukawa N, Kim YB, Lee A, Xue B, Mu J, Foufelle F, Ferre P, Birnbaum MJ et al. 2004 AMP-kinase regulates food intake by responding to hormonal and nutrient signals in the hypothalamus. Nature 428 569-574. (doi:10.1038/ nature02440)

Mitchell V, Bouret S, Beauvillain JC, Schilling A, Perret M, Kordon C \& Epelbaum J 2001 Comparative distribution of mRNA encoding the growth hormone secretagogue-receptor (GHS-R) in Microcebus 
murinus (Primate, lemurian) and rat forebrain and pituitary. Journal of Comparative Neurology 429 469-489. (doi:10.1002/ 1096-9861 (20010115) 429:3 < 469::AID-CNE8 > 3.0.CO;2-\#)

de Morentin PB \& López M 2010 "Mens sana in corpore sano": exercise and hypothalamic ER stress. PLoS Biology 8 e1000464. (doi:10.1371/journal.pbio.1000464)

Morrison CD, Xi X, White CL, Ye J \& Martin RJ 2007 Amino acids inhibit Agrp gene expression via an mTOR-dependent mechanism. American Journal of Physiology. Endocrinology and Metabolism 293 E165-E171. (doi:10.1152/ajpendo.00675.2006)

Murphy B, Nunes CN, Ronan JJ, Harper CM, Beall MJ, Hanaway M, Fairhurst AM, Van Der Ploeg LH, MacIntyre DE \& Mellin TN 1998 Melanocortin mediated inhibition of feeding behavior in rats. Neuropeptides 32 491-497. (doi:10.1016/S0143-4179(98)90077-4)

Murphy BA, Fakira KA, Song Z, Beuve A \& Routh VH 2009 AMPactivated protein kinase and nitric oxide regulate the glucose sensitivity of ventromedial hypothalamic glucose-inhibited neurons. American Journal of Physiology. Cell Physiology 297 C750-C758. (doi:10.1152/ajpcell.00127.2009)

Nahon JL, Presse F, Bittencourt JC, Sawchenko PE \& Vale W 1989 The rat melanin-concentrating hormone messenger ribonucleic acid encodes multiple putative neuropeptides coexpressed in the dorsolateral hypothalamus. Endocrinology 125 2056-2065. (doi:10. 1210/endo-125-4-2056)

Nakazato M, Murakami N, Date Y, Kojima M, Matsuo H, Kangawa K \& Matsukura S 2001 A role for ghrelin in the central regulation of feeding. Nature 409 194-198. (doi:10.1038/35051587)

Namkoong C, Kim MS, Jang PG, Han SM, Park HS, Koh EH, Lee WJ, Kim JY, Park IS, Park JY et al. 2005 Enhanced hypothalamic AMPactivated protein kinase activity contributes to hyperphagia in diabetic rats. Diabetes 54 63-68. (doi:10.2337/diabetes.54.1.63)

Nedungadi TP \& Briski KP 2007 Effects of estradiol on acute and recurrent insulin-induced hypoglycemia-associated patterns of arcuate neuropeptide $\mathrm{Y}$, proopiomelanocortin, and cocaine- and amphetamine-related transcript gene expression in the ovariectomized rat. Neuroendocrinology 86 270-276. (doi:10.1159/ 000109678)

Nguyen QH \& Wagner EJ 2006 Estrogen differentially modulates the cannabinoid-induced presynaptic inhibition of amino acid neurotransmission in proopiomelanocortin neurons of the arcuate nucleus. Neuroendocrinology 84 123-137. (doi:10.1159/000096996)

Nogueiras R, Tovar S, Mitchell SE, Rayner DV, Archer ZA, Dieguez C \& Williams LM 2004 Regulation of growth hormone secretagogue receptor gene expression in the arcuate nuclei of the rat by leptin and ghrelin. Diabetes 53 2552-2558. (doi:10.2337/diabetes.53.10. 2552)

Nogueiras R, Wiedmer P, Perez-Tilve D, Veyrat-Durebex C, Keogh JM, Sutton GM, Pfluger PT, Castaneda TR, Neschen S, Hofmann SM et al. 2007 The central melanocortin system directly controls peripheral lipid metabolism. Journal of Clinical Investigation 117 3475-3488. (doi:10.1172/JCI31743)

Nogueiras R, López M, Lage R, Pérez-Tilve D, Pfluger P, MendietaZeron H, Sakkou M, Wiedmer P, Benoit S, Datta R et al. 2008 $a$ Bsx, a novel hypothalamic factor linking feeding with locomotor activity, is regulated by energy availability. Endocrinology 149 3009-3015. (doi:10.1210/en.2007-1684)

Nogueiras R, Veyrat-Durebex C, Suchanek PM, Klein M, Tschop J, Caldwell C, Woods SC, Wittmann G, Watanabe M, Liposits Z et al. $2008 b$ Peripheral, but not central, CB1 antagonism provides food intake-independent metabolic benefits in diet-induced obese rats. Diabetes 57 2977-2991. (doi:10.2337/db08-0161)

Nogueiras R, Pérez-Tilve D, Veyrat-Durebex C, Morgan DA, Varela L, Haynes WG, Patterson TJ, Disse E, Pfluger P, López M et al. 2009 Direct control of peripheral lipid deposition by CNS GLP-1 receptor signaling is mediated by the sympathetic nervous system and blunted in diet induced obesity. Journal of Neuroscience $\mathbf{2 9}$ 5916-5925. (doi:10.1523/JNEUROSCI.5977-08.2009)
Nogueiras R, López M \& Diéguez C 2010 Regulation of lipid metabolism by energy availability: a role for the central nervous system. Obesity Reviews 11 185-201. (doi:10.1111/j.1467-789X.2009. 00669.x)

Obici S, Feng Z, Karkanias G, Baskin DG \& Rossetti L $2002 a$ Decreasing hypothalamic insulin receptors causes hyperphagia and insulin resistance in rats. Nature Neuroscience 5 566-572. (doi:10. 1038/nn0602-861)

Obici S, Zhang BB, Karkanias G \& Rossetti L 2002b Hypothalamic insulin signaling is required for inhibition of glucose production. Nature Medicine 8 1376-1382. (doi:10.1038/nm798)

Obici S, Feng Z, Arduini A, Conti R \& Rossetti L 2003 Inhibition of hypothalamic carnitine palmitoyltransferase-1 decreases food intake and glucose production. Nature Medicine 9 756-761. (doi:10. $1038 / \mathrm{nm} 873$ )

Ollmann MM, Wilson BD, Yang YK, Kerns JA, Chen Y, Gantz I \& Barsh GS 1997 Antagonism of central melanocortin receptors in vitro and in vivo by agouti-related protein. Science 278 135-138. (doi:10.1126/science.278.5335.135)

Osei-Hyiaman D, Depetrillo M, Harvey-White J, Bannon AW, Cravatt BF, Kuhar MJ, Mackie K, Palkovits M \& Kunos G 2005 Cocaine- and amphetamine-related transcript is involved in the orexigenic effect of endogenous anandamide. Neuroendocrinology 81 273-282. (doi:10.1159/000087925)

Oyadomari S \& Mori M 2004 Roles of CHOP/GADD153 in endoplasmic reticulum stress. Cell Death and Differentiation 11 381-389. (doi:10.1038/sj.cdd.4401373)

Ozcan L, Ergin AS, Lu A, Chung J, Sarkar S, Nie D, Myers MG Jr \& Ozcan U 2009 Endoplasmic reticulum stress plays a central role in development of leptin resistance. Cell Metabolism 9 35-51. (doi:10. 1016/j.cmet.2008.12.004)

Pagotto U, Marsicano G, Cota D, Lutz B \& Pasquali R 2006 The emerging role of the endocannabinoid system in endocrine regulation and energy balance. Endocrine Reviews 27 73-100. (doi:10.1210/er.2005-0009)

Pecqueur C, Bui T, Gelly C, Hauchard J, Barbot C, Bouillaud F, Ricquier D, Miroux B \& Thompson CB 2008 Uncoupling protein-2 controls proliferation by promoting fatty acid oxidation and limiting glycolysis-derived pyruvate utilization. FASEB Journal 22 9-18. (doi:10.1096/fj.07-8945com)

Peino R, Baldelli R, Rodriguez-Garcia J, Rodriguez-Segade S, Kojima M, Kangawa K, Arvat E, Ghigo E, Dieguez C \& Casanueva FF 2000 Ghrelin-induced growth hormone secretion in humans. European Journal of Endocrinology 143 R11-R14. (doi:10.1530/eje.0.143R011)

Peyron C, Tighe DK, van den Pol AN, de Lecea L, Heller HC, Sutcliffe JG \& Kilduff TS 1998 Neurons containing hypocretin (orexin) project to multiple neuronal systems. Journal of Neuroscience 18 9996-10015.

Plum L, Belgardt BF \& Bruning JC 2006 Central insulin action in energy and glucose homeostasis. Journal of Clinical Investigation 116 1761-1766. (doi:10.1172/JCI29063)

Plum L, Lin HV, Dutia R, Tanaka J, Aizawa KS, Matsumoto M, Kim AJ, Cawley NX, Paik JH, Loh YP et al. 2009 The obesity susceptibility gene Cpe links FoxO1 signaling in hypothalamic pro-opiomelanocortin neurons with regulation of food intake. Nature Medicine $\mathbf{1 5}$ 1195-1201. (doi:10.1038/nm.2026)

Pocai A, Lam TK, Gutierrez-Juarez R, Obici S, Schwartz GJ, Bryan J, Aguilar-Bryan L \& Rossetti L 2005a Hypothalamic K(ATP) channels control hepatic glucose production. Nature 434 1026-1031. (doi:10. 1038/nature03439)

Pocai A, Morgan K, Buettner C, Gutierrez-Juarez R, Obici S \& Rossetti L 2005b Central leptin acutely reverses diet-induced hepatic insulin resistance. Diabetes 54 3182-3189. (doi:10.2337/diabetes.54. 11.3182)

Pocai A, Lam TK, Obici S, Gutierrez-Juarez R, Muse ED, Arduini A \& Rossetti L 2006 Restoration of hypothalamic lipid sensing 
normalizes energy and glucose homeostasis in overfed rats. Journal of Clinical Investigation 116 1081-1091. (doi:10.1172/ JCI26640)

Qi J, Gong J, Zhao T, Zhao J, Lam P, Ye J, Li JZ, Wu J, Zhou HM \& Li P 2008 Downregulation of AMP-activated protein kinase by Cideamediated ubiquitination and degradation in brown adipose tissue. EMBO Journal 27 1537-1548. (doi:10.1038/emboj.2008.92)

Qu D, Ludwig DS, Gammeltoft S, Piper M, Pelleymounter MA, Cullen MJ, Mathes WF, Przypek R, Kanarek R \& Maratos-Flier E 1996 A role for melanin-concentrating hormone in the central regulation of feeding behaviour. Nature 380 243-247. (doi:10.1038/ 380243a0)

Raposinho PD, White RB \& Aubert ML 2003 The melanocortin agonist melanotan-II reduces the orexigenic and adipogenic effects of neuropeptide Y (NPY) but does not affect the NPY-driven suppressive effects on the gonadotropic and somatotropic axes in the male rat. Journal of Neuroendocrinology 15 173-181. (doi:10.1046/ j.1365-2826.2003.00962.x)

Ron D \& Habener JF 1992 CHOP, a novel developmentally regulated nuclear protein that dimerizes with transcription factors C/EBP and LAP and functions as a dominant-negative inhibitor of gene transcription. Genes and Development 6 439-453. (doi:10.1101/gad.6. 3.439)

Ropelle ER, Fernandes MF, Flores MB, Ueno M, Rocco S, Marin R, Cintra DE, Velloso LA, Franchini KG, Saad MJ et al. 2008 a Central exercise action increases the AMPK and mTOR response to leptin. PLoS ONE 3 e3856. (doi:10.1371/journal.pone.0003856)

Ropelle ER, Pauli JR, Fernandes MF, Rocco SA, Marin RM, Morari J, Souza KK, Dias MM, Gomes-Marcondes MC, Gontijo JA et al. $2008 b$ A central role for neuronal AMP-activated protein kinase (AMPK) and mammalian target of rapamycin (mTOR) in highprotein diet-induced weight loss. Diabetes 57 594-605. (doi:10. 2337/db07-0573)

Ropelle ER, Flores MB, Cintra DE, Rocha GZ, Pauli JR, Morari J, de Zouza CT, Moraes JC, Prada PO, Guadagnini D et al. 2010 IL-6 and IL-10 anti-inflammatory activity links exercise to hypothalamic insulin and leptin sensitivity through IKK $\beta$ and ER stress inhibition. PLoS Biology 8 e1000465. (doi:10.1371/journal.pbio.1000465)

Ruderman NB, Saha AK \& Kraegen EW 2003 Minireview: malonyl CoA, AMP-activated protein kinase, and adiposity. Endocrinology 144 5166-5171. (doi:10.1210/en.2003-0849)

Sakkou M, Wiedmer P, Anlag K, Hamm A, Seuntjens E, Ettwiller L, Tschop MH \& Treier M 2007 A role for brain-specific homeobox factor bsx in the control of hyperphagia and locomotory behavior. Cell Metabolism 5 450-463. (doi:10.1016/j.cmet.2007.05.007)

Sakurai T, Amemiya A, Ishii M, Matsuzaki I, Chemelli RM, Tanaka H, Williams SC, Richardson JA, Kozlowski GP, Wilson S et al. 1998 Orexins and orexin receptors: a family of hypothalamic neuropeptides and $\mathrm{G}$ protein-coupled receptors that regulate feeding behavior. Cell 92 573-585. (doi:10.1016/S0092-8674(00) 80949-6)

Sanacora G, Kershaw M, Finkelstein JA \& White JD 1990 Increased hypothalamic content of preproneuropeptide $\mathrm{Y}$ messenger ribonucleic acid in genetically obese Zucker rats and its regulation by food deprivation. Endocrinology 127 730-737. (doi:10.1210/endo127-2-730)

Sangiao-Alvarellos S, Vázquez MJ, Varela L, Nogueiras R, Saha AK, Cordido F, López M \& Diéguez C 2009 Central ghrelin regulates peripheral lipid metabolism in a growth hormone-independent fashion. Endocrinology 150 4562-4574. (doi:10.1210/en.2009-0482)

Sangiao-Alvarellos S, Varela L, Vázquez MJ, Boit KD, Saha AK, Cordido F, Diéguez C \& López M 2010 Influence of ghrelin and GH deficiency on AMPK and hypothalamic lipid metabolism. Journal of Neuroendocrinology 22 543-556. (doi:10.1111/j.1365-2826.2010. 01994.x)

Santos CX, Tanaka LY, Wosniak J \& Laurindo FR 2009 Mechanisms and implications of reactive oxygen species generation during the unfolded protein response: roles of endoplasmic reticulum oxidoreductases, mitochondrial electron transport, and NADPH oxidase. Antioxidants $\mathcal{E}$ Redox Signaling 11 2409-2427. (doi:10. 1089/ars.2009.2625)

Savontaus E, Conwell IM \& Wardlaw SL 2002 Effects of adrenalectomy on AGRP, POMC, NPY and CART gene expression in the basal hypothalamus of fed and fasted rats. Brain Research 958 130-138. (doi:10.1016/S0006-8993(02)03674-0)

Schwartz MW, Marks JL, Sipols AJ, Baskin DG, Woods SC, Kahn SE \& Porte D Jr 1991 Central insulin administration reduces neuropeptide Y mRNA expression in the arcuate nucleus of food-deprived lean $(\mathrm{Fa} / \mathrm{Fa})$ but not obese (fa/fa) Zucker rats. Endocrinology 128 2645-2647. (doi:10.1210/endo-128-5-2645)

Schwartz MW, Sipols AJ, Marks JL, Sanacora G, White JD, Scheurink A, Kahn SE, Baskin DG, Woods SC, Figlewicz DP et al. 1992 Inhibition of hypothalamic neuropeptide Y gene expression by insulin. Endocrinology 130 3608-3616. (doi:10.1210/en.130.6.3608)

Schwartz MW, Seeley RJ, Woods SC, Weigle DS, Campfield LA, Burn P \& Baskin DG 1997 Leptin increases hypothalamic pro-opiomelanocortin mRNA expression in the rostral arcuate nucleus. Diabetes 46 2119-2123. (doi:10.2337/diabetes.46.12.2119)

Scrocchi LA, Brown TJ, MaClusky N, Brubaker PL, Auerbach AB, Joyner AL \& Drucker DJ 1996 Glucose intolerance but normal satiety in mice with a null mutation in the glucagon-like peptide 1 receptor gene. Nature Medicine 2 1254-1258. (doi:10.1038/nm11961254)

Seo S, Ju S, Chung H, Lee D \& Park S 2008 Acute effects of glucagonlike peptide-1 on hypothalamic neuropeptide and AMP activated kinase expression in fasted rats. Endocrine Journal 55 867-874. (doi:10.1507/endocrj.K08E-091)

Seoane LM, López M, Tovar S, Casanueva F, Señarís R \& Diéguez C 2003 Agouti-related peptide, neuropeptide Y, and somatostatinproducing neurons are targets for ghrelin actions in the rat hypothalamus. Endocrinology 144 544-551. (doi:10.1210/en.2002220795)

Sheets AR, Fulop P, Derdak Z, Kassai A, Sabo E, Mark NM, Paragh G, Wands JR \& Baffy G 2008 Uncoupling protein-2 modulates the lipid metabolic response to fasting in mice. American Journal of Physiology. Gastrointestinal and Liver Physiology 294 G1017-G1024. (doi:10.1152/ ajpgi.00016.2008)

Shimizu H, Arima H, Watanabe M, Goto M, Banno R, Sato I, Ozaki N, Nagasaki H \& Oiso Y 2008 Glucocorticoids increase neuropeptide Y and agouti-related peptide gene expression via AMP-activated protein kinase signaling in the arcuate nucleus of rats. Endocrinology 149 4544-4553. (doi:10.1210/en.2008-0229)

Shimizu-Albergine M, Ippolito DL \& Beavo JA 2001 Downregulation of fasting-induced cAMP response element-mediated gene induction by leptin in neuropeptide $\mathrm{Y}$ neurons of the arcuate nucleus. Journal of Neuroscience 21 1238-1246.

Sindelar DK, Mystkowski P, Marsh DJ, Palmiter RD \& Schwartz MW 2002 Attenuation of diabetic hyperphagia in neuropeptide Y-deficient mice. Diabetes 51 778-783. (doi:10.2337/diabetes. 51.3.778)

Sindelar DK, Ste ML, Miura GI, Palmiter RD, McMinn JE, Morton GJ \& Schwartz MW 2004 Neuropeptide Y is required for hyperphagic feeding in response to neuroglucopenia. Endocrinology 145 33633368. (doi:10.1210/en.2003-1727)

Sipols AJ, Baskin DG \& Schwartz MW 1995 Effect of intracerebroventricular insulin infusion on diabetic hyperphagia and hypothalamic neuropeptide gene expression. Diabetes 44 147-151. (doi:10.2337/ diabetes.44.2.147)

Smith RG 2005 Development of growth hormone secretagogues. Endocrine Reviews 26 346-360. (doi:10.1210/er.2004-0019)

Sorensen A, Travers MT, Vernon RG, Price NT \& Barber MC 2002 Localization of messenger RNAs encoding enzymes associated with malonyl-CoA metabolism in mouse brain. Brain Research. Gene Expression Patterns 1 167-173. (doi:10.1016/ S1567-133X(02)00013-3) 
Steinberg GR, Michell BJ, van Denderen BJ, Watt MJ, Carey AL, Fam BC, Andrikopoulos S, Proietto J, Gorgun CZ, Carling D et al. $2006 a$ Tumor necrosis factor $\alpha$-induced skeletal muscle insulin resistance involves suppression of AMP-kinase signaling. Cell Metabolism 4 465-474. (doi:10.1016/j.cmet.2006.11.005)

Steinberg GR, Watt MJ, Fam BC, Proietto J, Andrikopoulos S, Allen AM, Febbraio MA \& Kemp BE $2006 b$ Ciliary neurotrophic factor suppresses hypothalamic AMP-kinase signaling in leptinresistant obese mice. Endocrinology 147 3906-3914. (doi:10.1210/ en.2005-1587)

Stephens TW, Basinski M, Bristow PK, Bue-Valleskey JM, Burgett SG , Craft L, Hale J, Hoffmann J, Hsiung HM, Kriauciunas A et al. 1995 The role of neuropeptide $\mathrm{Y}$ in the antiobesity action of the obese gene product. Nature 377 530-532. (doi:10.1038/ $377530 \mathrm{a} 0)$

Stoppa GR, Cesquini M, Roman EA, Prada PO, Torsoni AS, Romanatto T, Saad MJ, Velloso LA \& Torsoni MA 2008 Intracerebroventricular injection of citrate inhibits hypothalamic AMPK and modulates feeding behavior and peripheral insulin signaling. Journal of Endocrinology 198 157-168. (doi:10.1677/JOE-07-0428)

Sun Y, Wang P, Zheng H \& Smith RG 2004 Ghrelin stimulation of growth hormone release and appetite is mediated through the growth hormone secretagogue receptor. PNAS 101 4679-4684. (doi:10.1073/pnas.0305930101)

Swart I, Jahng JW, Overton JM \& Houpt TA 2002 Hypothalamic NPY, AGRP, and POMC mRNA responses to leptin and refeeding in mice. American Journal of Physiology. Regulatory, Integrative and Comparative Physiology 283 R1020-R1026. (doi:10.1152/ajpregu. 00501.2001)

Tagawa Y, Hiramatsu N, Kasai A, Hayakawa K, Okamura M, Yao J \& Kitamura M 2008 Induction of apoptosis by cigarette smoke via ROS-dependent endoplasmic reticulum stress and CCAAT/ enhancer-binding protein-homologous protein (CHOP). Free Radical Biology and Medicine 45 50-59. (doi:10.1016/j.freeradbiomed.2008.03.003)

Takaya K, Ariyasu H, Kanamoto N, Iwakura H, Yoshimoto A, Harada M, Mori K, Komatsu Y, Usui T, Shimatsu A et al. 2000 Ghrelin strongly stimulates growth hormone release in humans. Journal of Clinical Endocrinology and Metabolism 85 4908-4911. (doi:10.1210/jc.85.12. 4908)

Tang QQ \& Lane MD 2000 Role of C/EBP homologous protein (CHOP-10) in the programmed activation of CCAAT/enhancerbinding protein- $\beta$ during adipogenesis. PNAS 97 12446-12450. (doi:10.1073/pnas.220425597)

Tannenbaum GS, Lapointe M, Beaudet A \& Howard AD 1998 Expression of growth hormone secretagogue-receptors by growth hormone- releasing hormone neurons in the mediobasal hypothalamus. Endocrinology 139 4420-4423. (doi:10.1210/en.139.10. 4420)

Theander-Carrillo C, Wiedmer P, Cettour-Rose P, Nogueiras R, PerezTilve D, Pfluger P, Castaneda TR, Muzzin P, Schurmann A, Szanto I et al. 2006 Ghrelin action in the brain controls adipocyte metabolism. Journal of Clinical Investigation 116 1983-1993. (doi:10. 1172/JCI25811)

Tkacs NC \& Levin BE 2004 Obesity-prone rats have preexisting defects in their counterregulatory response to insulin-induced hypoglycemia. American Journal of Physiology. Regulatory, Integrative and Comparative Physiology 287 R1110-R1115.

Tkacs NC, Dunn-Meynell AA \& Levin BE 2000 Presumed apoptosis and reduced arcuate nucleus neuropeptide $\mathrm{Y}$ and pro-opiomelanocortin mRNA in non-coma hypoglycemia. Diabetes 49 820-826. (doi:10.2337/diabetes.49.5.820)

Tong Q, Ye C, McCrimmon RJ, Dhillon H, Choi B, Kramer MD, Yu J, Yang Z, Christiansen LM, Lee CE et al. 2007 Synaptic glutamate release by ventromedial hypothalamic neurons is part of the neurocircuitry that prevents hypoglycemia. Cell Metabolism $\mathbf{5}$ 383-393. (doi:10.1016/j.cmet.2007.04.001)
Tovar S, Nogueiras R, Tung LY, Castaneda TR, Vazquez MJ, Morris A, Williams LM, Dickson SL \& Dieguez C 2005 Central administration of resistin promotes short-term satiety in rats. European Journal of Endocrinology 153 R1-R5. (doi:10.1530/eje.1.01999)

Trivedi P, Jiang M, Tamvakopoulos CC, Shen X, Yu H, Mock S, FenykMelody J, Van Der Ploeg LH \& Guan XM 2003 Exploring the site of anorectic action of peripherally administered synthetic melanocortin peptide MT-II in rats. Brain Research 977 221-230. (doi:10. 1016/S0006-8993(03)02683-0)

Tschop M, Smiley DL \& Heiman ML 2000 Ghrelin induces adiposity in rodents. Nature 407 908-913. (doi:10.1038/35038090)

Tschop M, Wawarta R, Riepl RL, Friedrich S, Bidlingmaier M, Landgraf R \& Folwaczny C $2001 a$ Post-prandial decrease of circulating human ghrelin levels. Journal of Endocrinological Investigation 24 RC19-RC21.

Tschop M, Weyer C, Tataranni PA, Devanarayan V, Ravussin E \& Heiman ML 2001 $b$ Circulating ghrelin levels are decreased in human obesity. Diabetes 50 707-709. (doi:10.2337/diabetes.50.4.707)

Tsubone T, Masaki T, Katsuragi I, Tanaka K, Kakuma T \& Yoshimatsu H 2005 Ghrelin regulates adiposity in white adipose tissue and UCP1 mRNA expression in brown adipose tissue in mice. Regulatory Peptides 130 97-103. (doi:10.1016/j.regpep.2005.04.004)

Vázquez MJ, González CR, Varela L, Lage R, Tovar S, SangiaoAlvarellos S, Williams LM, Vidal-Puig A, Nogueiras R, López M et al. 2008 Central resistin regulates hypothalamic and peripheral lipid metabolism in a nutritional-dependent fashion. Endocrinology 149 4534-4543. (doi:10.1210/en.2007-1708)

Verty AN, McFarlane JR, McGregor IS \& Mallet PE 2004 Evidence for an interaction between CB1 cannabinoid and melanocortin MCR-4 receptors in regulating food intake. Endocrinology 145 3224-3231. (doi:10.1210/en.2004-0059)

Vrang N, Larsen PJ, Tang-Christensen M, Larsen LK \& Kristensen P 2003 Hypothalamic cocaine-amphetamine regulated transcript (CART) is regulated by glucocorticoids. Brain Research 965 45-50. (doi:10.1016/S0006-8993(02)04064-7)

Wang W, Liu Y, Chen Y, Cao C, Xiang Y, Zhang D, Han L, Zhao H \& Liu G 2010 $a$ Inhibition of Foxol mediates protective effects of ghrelin against lipotoxicity in MIN6 pancreatic $\beta$-cells. Peptides 31 307-314. (doi:10.1016/j.peptides.2009.11.011)

Wang W, Zhang D, Zhao H, Chen Y, Liu Y, Cao C, Han L \& Liu G $2010 b$ Ghrelin inhibits cell apoptosis induced by lipotoxicity in pancreatic $\beta$-cell line. Regulatory Peptides 161 43-50. (doi:10.1016/j.regpep. 2009.12.017)

Watanabe M, Arima H, Fukushima K, Goto M, Shimizu H, Hayashi M, Banno R, Sato I, Ozaki N, Nagasaki H et al. 2008 Direct and indirect modulation of neuropeptide $\mathrm{Y}$ gene expression in response to hypoglycemia in rat arcuate nucleus. FEBS Letters 582 3632-3638. (doi:10.1016/j.febslet.2008.09.045)

Wen JP, Liu CE, Hu YT, Chen G \& Lin LX 2010 Globular adiponectin regulates energy homeostasis through AMP-activated protein kinase-acetyl-CoA carboxylase (AMPK/ACC) pathway in the hypothalamus. Molecular and Cellular Biochemistry 344 109-115. (doi:10.1007/s11010-010-0534-2)

Willesen MG, Kristensen P \& Romer J 1999 Co-localization of growth hormone secretagogue receptor and NPY mRNA in the arcuate nucleus of the rat. Neuroendocrinology 70 306-316. (doi:10.1159/ 000054491)

Wilson BD, Bagnol D, Kaelin CB, Ollmann MM, Gantz I, Watson SJ \& Barsh GS 1999 Physiological and anatomical circuitry between agouti-related protein and leptin signaling. Endocrinology 140 2387-2397. (doi:10.1210/en.140.5.2387)

Wolfgang MJ \& Lane MD 2008 Hypothalamic malonyl-coenzyme A and the control of energy balance. Molecular Endocrinology 22 2012-2020. (doi:10.1210/me.2007-0538)

Wolfgang MJ, Kurama T, Dai Y, Suwa A, Asaumi M, Matsumoto S, Cha SH, Shimokawa T \& Lane MD 2006 The brain-specific carnitine palmitoyltransferase-1c regulates energy homeostasis. PNAS 103 7282-7287. (doi:10.1073/pnas.0602205103) 
Wolfgang MJ, Cha SH, Sidhaye A, Chohnan S, Cline G, Shulman GI \& Lane MD 2007 Regulation of hypothalamic malonyl-CoA by central glucose and leptin. PNAS 104 19285-19290. (doi:10.1073/pnas. 0709778104)

Won JC, Jang PG, Namkoong C, Koh EH, Kim SK, Park JY, Lee KU \& Kim MS 2009 Central administration of an endoplasmic reticulum stress inducer inhibits the anorexigenic effects of leptin and insulin. Obesity 17 1861-1865. (doi:10.1038/oby.2009.194)

Woods SC, Lotter EC, McKay LD \& Porte D Jr 1979 Chronic intracerebroventricular infusion of insulin reduces food intake and body weight of baboons. Nature 282 503-505. (doi:10.1038/ 282503a0)

Woods A, Dickerson K, Heath R, Hong SP, Momcilovic M, Johnstone SR, Carlson M \& Carling D $2005 \mathrm{Ca}(2+)$ /calmodulin-dependent protein kinase kinase- $\beta$ acts upstream of AMP-activated protein kinase in mammalian cells. Cell Metabolism 2 21-33. (doi:10.1016/j. cmet.2005.06.005)

Wortley KE, Del Rincon JP, Murray JD, Garcia K, Iida K, Thorner MO \& Sleeman MW 2005 Absence of ghrelin protects against early-onset obesity. Journal of Clinical Investigation 115 3573-3578. (doi:10.1172/ JCI26003)

Wren AM, Small CJ, Ward HL, Murphy KG, Dakin CL, Taheri S, Kennedy AR, Roberts GH, Morgan DG, Ghatei MA et al. 2000 The novel hypothalamic peptide ghrelin stimulates food intake and growth hormone secretion. Endocrinology 141 4325-4328. (doi:10. 1210/en.141.11.4325)

Wren AM, Seal LJ, Cohen MA, Brynes AE, Frost GS, Murphy KG, Dhillo WS, Ghatei MA \& Bloom SR $2001 a$ Ghrelin enhances appetite and increases food intake in humans. Journal of Clinical Endocrinology and Metabolism 86 5992. (doi:10.1210/jc.86.12.5992)

Wren AM, Small CJ, Abbott CR, Dhillo WS, Seal I, Cohen MA, Batterham RL, Taheri S, Stanley SA, Ghatei MA et al. $2001 b$ Ghrelin causes hyperphagia and obesity in rats. Diabetes 50 2540-2547. (doi:10.2337/diabetes.50.11.2540)

Xie M, Zhang D, Dyck JR, Li Y, Zhang H, Morishima M, Mann DL, Taffet GE, Baldini A, Khoury DS et al. 2006 A pivotal role for endogenous TGF- $\beta$-activated kinase-1 in the LKB1/AMP-activated protein kinase energy-sensor pathway. PNAS 103 17378-17383. (doi:10.1073/pnas.0604708103)

Xu B, Dube MG, Kalra PS, Farmerie WG, Kaibara A, Moldawer LL, Martin D \& Kalra SP 1998 Anorectic effects of the cytokine, ciliary neurotropic factor, are mediated by hypothalamic neuropeptide $\mathrm{Y}$ : comparison with leptin. Endocrinology 139 466-473. (doi:10.1210/ en.139.2.466)
Yang J, Brown MS, Liang G, Grishin NV \& Goldstein JL 2008 Identification of the acyltransferase that octanoylates ghrelin, an appetite-stimulating peptide hormone. Cell 132 387-396. (doi:10. 1016/j.cell.2008.01.017)

Yang CS, Lam CK, Chari M, Cheung GW, Kokorovic A, Gao S, Leclerc I, Rutter GA \& Lam TK 2010 Hypothalamic AMP-activated protein kinase regulates glucose production. Diabetes 59 2435-2443. (doi:10. 2337/db10-0221)

Zhang X, Zhang G, Zhang H, Karin M, Bai H \& Cai D 2008 Hypothalamic IKK $\beta / N F-\kappa B$ and ER stress link overnutrition to energy imbalance and obesity. Cell 135 61-73. (doi:10.1016/j.cell. 2008.07.043)

Zhang GG, Teng X, Liu Y, Cai Y, Zhou YB, Duan XH, Song JQ, Shi Y, Tang CS, Yin XH et al. 2009 Inhibition of endoplasm reticulum stress by ghrelin protects against ischemia/reperfusion injury in rat heart. Peptides 30 1109-1116. (doi:10.1016/j.peptides.2009.03.024)

Zheng H, Corkern MM, Crousillac SM, Patterson LM, Phifer CB \& Berthoud HR 2002 Neurochemical phenotype of hypothalamic neurons showing Fos expression $23 \mathrm{~h}$ after intracranial AgRP. American Journal of Physiology. Regulatory, Integrative and Comparative Physiology 282 R1773-R1781.

Zhou G, Myers R, Li Y, Chen Y, Shen X, Fenyk-Melody J, Wu M, Ventre J, Doebber T, Fujii $\mathrm{N}$ et al. 2001 Role of AMP-activated protein kinase in mechanism of metformin action. Journal of Clinical Investigation $\mathbf{1 0 8}$ $1167-1174$.

Zigman JM, Nakano Y, Coppari R, Balthasar N, Marcus JN, Lee CE, Jones JE, Deysher AE, Waxman AR, White RD et al. 2005 Mice lacking ghrelin receptors resist the development of diet-induced obesity. Journal of Clinical Investigation 115 3564-3572. (doi:10.1172/JCI26002)

Zigman JM, Jones JE, Lee CE, Saper CB \& Elmquist JK 2006 Expression of ghrelin receptor mRNA in the rat and the mouse brain. Journal of Comparative Neurology 494 528-548. (doi:10.1002/cne.20823)

Ziotopoulou M, Erani DM, Hileman SM, Bjorbaek C \& Mantzoros CS 2000 Unlike leptin, ciliary neurotrophic factor does not reverse the starvation-induced changes of serum corticosterone and hypothalamic neuropeptide levels but induces expression of hypothalamic inhibitors of leptin signaling. Diabetes 49 1890-1896. (doi:10.2337/diabetes.49.11.1890)

Zorrilla EP, Iwasaki S, Moss JA, Chang J, Otsuji J, Inoue K, Meijler MM \& Janda KD 2006 Vaccination against weight gain. PNAS 103 13226-13231. (doi:10.1073/pnas.0605376103)

Received in final form 6 December 2010

Accepted 17 December 2010

Made available online as an Accepted Preprint 17 December 2010 